\title{
TISSUE ENGINEERING AND REGENERATIVE APPROACHES TO IMPROVING THE HEALING OF LARGE BONE DEFECTS
}

S. Verrier ${ }^{1,11 *}$, M. Alini ${ }^{1,11}$, E. Alsberg ${ }^{2,11}$, S.R. Buchman 3,11 , D. Kelly,11, M.W. Laschke ${ }^{5,11}$, M.D. Menger ${ }^{5,11}$, W.L.

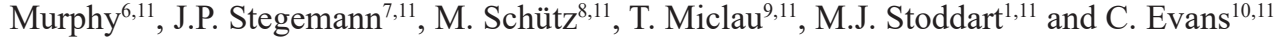

${ }^{1} \mathrm{AO}$ Research Institute Davos, Davos, Switzerland

${ }^{2}$ Departments of Biomedical Engineering and Orthopaedic Surgery, Case Western Reserve University, Cleveland, $\mathrm{OH}, \mathrm{USA}$

${ }^{3}$ Department of Surgery, University of Michigan Medical School, Ann Arbor, Michigan, USA

${ }^{4}$ Trinity Centre for Bioengineering, Trinity Biomedical Sciences Institute, Trinity College Dublin, Dublin, Ireland

${ }^{5}$ Institute for Clinical and Experimental Surgery, Saarland University, 66421Homburg/Saar, Germany

${ }^{6}$ Department of Biomedical Engineering, University of Wisconsin, Madison, WI, USA

${ }^{7}$ Department of Biomedical Engineering, University of Michigan, Ann Arbor, Michigan, USA

${ }^{8}$ Institute of Health and Biomedical Innovation and Medical Engineering Research Facility,

Queensland University of Technology, Brisbane, Australia

${ }^{9}$ Department of Orthopaedic Surgery, University of California, San Francisco, Orthopaedic Trauma Institute,

University of California, San Francisco/San Francisco General Hospital, San Francisco, CA, USA

${ }^{10}$ Rehabilitation Medicine Research Center, Mayo Clinic, 200 First Street SW, Rochester, USA

${ }^{11}$ Collaborative Research Partner Large Bone Defect Healing Program of AO Foundation, Davos, Switzerland

(All authors contributed equally to this work)

\begin{abstract}
Despite the high innate regenerative capacity of bone, large osseous defects fail to heal and remain a clinical challenge. Healing such defects requires the formation of large amounts of bone in an environment often rendered hostile to osteogenesis by damage to the surrounding soft tissues and vasculature. In recent years, there have been intensive research efforts directed towards tissue engineering and regenerative approaches designed to overcome this multifaceted challenge. In this paper, we describe and critically evaluate the state-of-the-art approaches to address the various components of this intricate problem. The discussion includes (i) the properties of synthetic and natural scaffolds, their use in conjunction with cell and growth factor delivery, (ii) their vascularisation, (iii) the potential of gene therapies and (iv) the role of the mechanical environment. In particular, we present a critical analysis of where the field stands, and how it can move forward in a coordinated fashion.
\end{abstract}

Keywords: Bone, vascularisation, scaffolds, gene therapy, stem cells, drug delivery, large bone defect, tissue engineering, regenerative medicine, translational and preclinical research.

\footnotetext{
*Address for correspondence:

Dr Sophie Verrier

AO Research Institute Davos

Clavadelerstrasse 8

7270 Davos Platz, Switzerland
}

Phone: +41814142211

Direct: +41814142448

Fax: +41814142288

Email: sophie.verrier@aofoundation.org

\section{Introduction}

The healing of large bone defects is a major clinical challenge. Although bone possesses remarkable repair and regenerative powers of its own, there are numerous clinical conditions in which the size, location, and/or local environment of the bone defect results in impaired healing. Large bone defects are a problem in craniomaxillofacial surgery, as well as in orthopaedics more generally. Examples of large bone defects include tumour resections, infection, fractures accompanied by substantial soft tissue trauma, congenital deformities and segmental loss. In each of these cases, the large volume of tissue that needs to be replaced makes it very challenging to achieve sufficient quantity and quality of new bone formation. In addition, the healing of larger defects is critically dependent on the presence of an appropriate vascular supply to support regeneration and remodelling of new bone tissue.

In clinical practice the standard treatment for large bone defects is the use of autogenous or allogenic bone grafting to provide an osteogenic and/or osteoconductive stimulus, and thereby promote bone regeneration and union. However, insufficient volume of available tissue, donor site morbidity (autogenous), inconsistent osteogenic activity, late biomechanical failures, and the possibility of allogenic disease transmission reduce enthusiasm for their use. While great progress has been made with the use of osteoconductive bone graft substitutes and distraction osteogenesis, it is clear that complex clinical cases where novel therapies are required still exist. Finally, the challenging wound healing environment in which large bone defect restoration often needs to take place, mandates a strategy that both fills the bone gap and promotes vascularisation and repair. Although vascularised free flaps are currently an important and successful clinical option to address these concerns, it requires a long involved and often risky operation, with attendant extended hospitalisation and high cost. These challenges have motivated the field of 
musculoskeletal tissue engineering to find a solution that will aid the surgeon and the patient in tackling some of the most difficult and challenging reconstructive conundrums in both orthopaedic and craniofacial surgery. The general strategy was elegantly summarised in the Giannoudis Diamond concept, whereby the final outcome is dictated by the combination of osteogenic cells, osteoconductive scaffolds, growth factors and the mechanical environment (Giannoudis et al., 2007).

This review covers the techniques and strategies that have been developed to address the multifaceted challenges posed by the complicated problem of large bone defect healing (Fig. 1). The term "large bone defect" is used here in the sense of defects that are too large to heal spontaneously i.e. are of critical size. The review emphasises strategies based upon tissue engineering and regenerative medicine, sometimes abbreviated collectively as TERM to emphasise their overlapping nature. Unlike fractures, critical size segmental defects have no natural healing process and thus no native biology to model. Rather, TERM for large bone defects engages a variety of approaches, including scaffold design and selection, drug and morphogen delivery, cell- and gene-based therapies, vascularisation strategies, and mechanical environments that can be used to promote regeneration of bone. The uniqueness of large bone defects is the size of the void that needs to be filled and vascularised, all in the absence of local endogenous osteogenic signals. The goal here is to give an overview of the components that have been applied to the problem to date, as well as to provide insight into how these components can be combined in future more advanced therapies.

\section{Scaffolds}

Requirements for a bone regeneration scaffold include mechanical properties (e.g. desired stiffness and compression resistance), degradability, macro- and microporosity, and nanometre-scale topography. Encompassing all of these requirements into one material or composite is challenging and limits the number of suitable base materials that would also have an expeditious route to clinical application. In the following we describe some of the materials being actively investigated for use in large bone defects. The examples used are far from being an exhaustive list.

\section{Natural scaffolds}

Many tissue engineering strategies employ scaffold materials to provide both mechanical support and biological function. A logical approach to scaffold design is to mimic the materials and architectures found in native tissues. To this end, a variety of extracellular matrix (ECM) proteins, polysaccharides and other "naturally-derived" materials have been used to create scaffolds for bone tissue engineering. ECM-derived scaffolds have the advantage that cells can recognise and bind to them by specific cell surface receptors, and thereby can receive biochemical signals directly from the scaffold (Shekaran and Garcia, 2011; Siebers et al., 2005). In most cases, cells can also

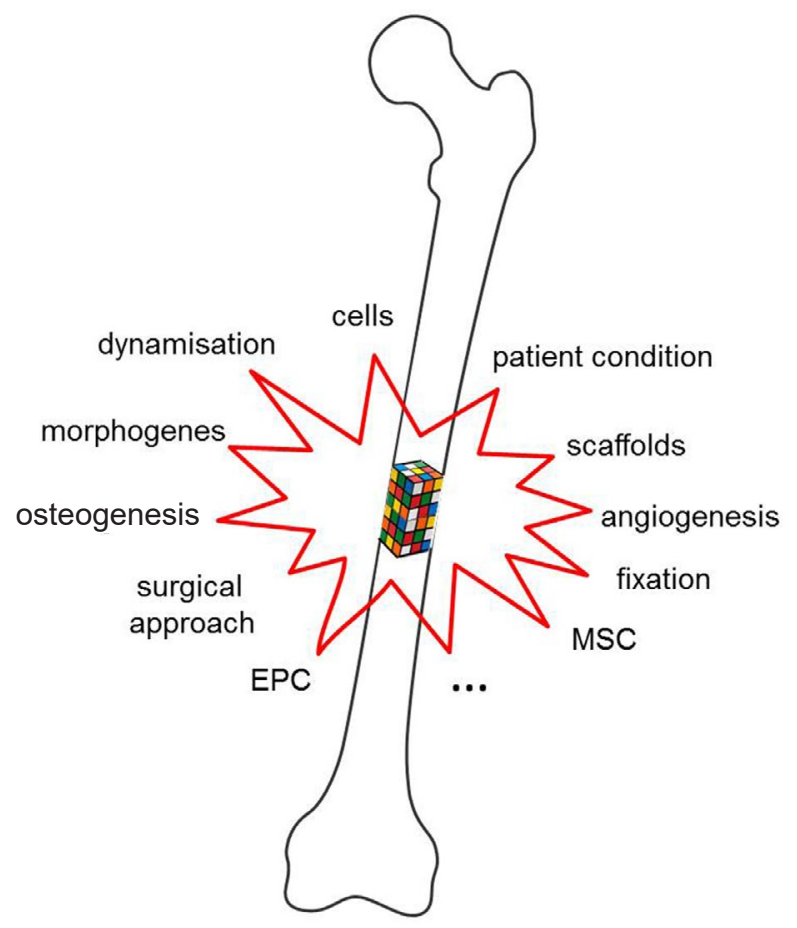

Fig. 1. Large bone defect: a multifaceted challenge. Bone healing is a complex process involving the interplay of many factors and well-orchestrated mechanisms. Tissue engineering approaches aim to resume the complexity of these events by combining scaffolds, cells, growth factors and mechanical environment. The choice of cells, their association or not with scaffolds, the local delivery of growth factors, the application mechanical stimulation of the defect (e.g. active dynamisation and timing), but also the patient condition and the surgical approach are as many factors influencing the healing outcome. Here, we give an overview of the techniques and strategies that have been developed in the past 10 years to address the complex situation of large bone defects.

degrade, synthesise, and remodel these natural matrices in response to environmental cues (Ferreira et al., 2012). For the repair of large bone defects, the mechanical and space-filling attributes of the scaffold are of primary importance. Pure naturally-derived materials, such as collagen scaffolds, typically have inferior mechanical properties relative to both the tissues from which they are derived and to synthetic polymer scaffolds (Gibbs et al., 2014). Accordingly, their use in large bone defects without additional structural support is challenging. For this reason, there is a growing interest in decellularisation of harvested tissues for use as scaffolds, in an effort to keep the native architecture and compositional complexity intact (Cheng et al., 2014). In addition, a variety of composite materials that combine the desirable features of specific protein and polysaccharide components of the ECM have been developed and used as scaffolds in bone tissue engineering (Wang and Stegemann, 2010).

The collagen superfamily of proteins consists of over 25 molecular isoforms. The most common form is type I collagen, which is a main structural constituent of many 
tissues, and is the predominant non-mineral component of bone. Collagen "sponges" are typically generated by freeze-drying collagen based slurries, creating a porous architecture (O’Brien, 2011). Such sponges are used widely as haemostatic agents, and also have been used in bone repair as a delivery vehicle for bone morphogenetic proteins (BMPs) (Geiger et al., 2003; Wei et al., 2012) or as gene delivery platforms (Curtin et al., 2012; Tierney et al., 2013).. Their expanded use is being investigated in preclinical studies for a variety of orthopaedic applications (d'Aquino et al., 2009; Hosseinkhani et al., 2006). Type I collagen has also been reconstituted into fibrillar form by electrospinning (Huang et al., 2001; Matthews et al., 2002). Efforts to further mimic the composition and function of bone have led to collagen-ceramic composites (Wahl and Czernuszka, 2006). Hydroxyapatite or tricalcium phosphates are often used in this application to represent the mineral content of bone (Gleeson et al., 2010; Zheng et al., 2014).

Chitosan is an aminated polysaccharide that is derived from the deacetylation of chitin, a structural component of the exoskeleton of crustaceans and some fungi. Chitosan can be made water soluble, and has been used in ways similar to collagen to make sponges, meshes and scaffold materials for bone tissue engineering (Costa-Pinto et al., 2011; Heinemann et al., 2010). In scaffold form, pure chitosan allows cell attachment and has been suggested to be osteoinductive (Di et al., 2005). Composites of chitosan, with other matrix components to improve its mechanical properties, are more commonly used for orthopaedic applications (Venkatesan et al., 2012). Blends of chitosan and other materials have been electrospun into fibre meshes (Chen et al., 2011; Zhang et al., 2008), and composites have been used in sponge format, including combination with other polysaccharides (Park et al., 2013), proteins (Wang et al., 2013), and mineral (Pighinelli and Kucharska, 2013). The free amine groups on the chitosan molecule allow it to be crosslinked with the same agents as used for protein matrices (Reves et al., 2013; Wang and Stegemann, 2011), which can increase its mechanical strength and resistance to degradation. In addition, the positive charge on the chitosan molecule allows the material to be used for drug and gene delivery directly from the scaffold (Cao et al., 2012b; Goncalves et al., 2012).

Hydrogels form another class of natural polymer scaffolds. These materials are hydrated, interconnected networks of polymer chains. An inherent advantage of such hydrogels is that they can be delivered using minimally invasive techniques, will fill defects of complex shapes and can be combined with cells and/or osteoinductive factors (Drury and Mooney, 2003). Alginate hydrogels have been used for gene (Krebs et al., 2010) and growth factor delivery (Kolambkar et al., 2011) and such systems have been shown to promote functional repair of criticallysized bone defects. Promising results have been obtained using natural hydrogels such as fibrin (Chung et al., 2007; Woodruff et al., 2007) and gelatin (Yamamoto et al., 2003; Yamamoto et al., 2006) as delivery vehicles for therapeutic factors for bone regeneration. One concern with certain classes of hydrogels for large bone healing is insufficient degradation of hydrogel (Rizzi et al., 2006), which may impede vascularisation of the implant. Such problems can potentially be overcome by modulating the hydrogel to accelerate its rate of degradation (Alsberg et al., 2001; Jeon et al., 2009). Hydrogels typically do not have compressionresistant mechanical properties, but can be included within other common orthopaedic devices (e.g. titanium cages) and used to stimulate new bone formation.

Demineralised bone matrix (DBM) is an example of a natural biomaterial that is commonly used clinically as a bone graft substitute (Urist, 1965). Such grafts are typically produced by the acid extraction of the mineral content from allogeneic bone and contain growth factors, other non-collagenous proteins and type I collagen (Sawkins et al., 2013). The rigorous processing and sterilisation that such grafts must undergo prior to implantation can negatively impact their osteoinductive properties which may at least partially explain the variable results seen with DMB (Gruskin et al., 2012; Peterson et al., 2004). To overcome such limitations, DBM can also be used as a delivery system for novel therapeutics (Lieberman et al., 1999). Decellularised ECM derived from other mammalian tissues such as small intestine submucosa have been used as biological scaffolds for bone regeneration (Badylak et al., 2009; Kim et al., 2010; Moore et al., 2004). It has also been demonstrated that bone-like ECM synthesised in vitro by osteoblastic cells can enhance osteogenesis of mesenchymal stem cells (MSCs) (Datta et al., 2005), and MSC-derived ECM enhances the retention of implanted cells into the remodelling phase of healing, resulting in reproducible and complete repair of critical-sized bone defects in mice (Zeitouni et al., 2012).

\section{Synthetic scaffolds}

Investigators have developed a variety of synthetic scaffolds for large bone defect healing, and a common approach involves mimicry of some aspects of the native bone ECM.

The catalogue of synthetic bone biomaterials used in critical sized defects features a wide range of biominerals, including hydroxyapatite, $\beta$-tricalcium phosphate, amorphous calcium phosphate, calcium silicate bioactive glasses, and biphasic calcium phosphates. The bone-like mineral layer formed on the surface of these materials has been shown to influence critical components of the bone formation process, including proliferation of bone-precursor cells (Chou et al., 2005), osteogenic differentiation of bone-forming cells (e.g. marrowderived MSCs, adipose-derived MSCs, pre-osteoblasts, and osteoblasts) (Barradas et al., 2012; Chou et al., 2005; Murphy et al., 2005), and localised sequestering of bone growth factors (Suarez-Gonzalez et al., 2012). Recent studies suggest that released mineral ions (e.g. calcium (Barradas et al., 2012), phosphate (Shih et al., 2014), magnesium (Hussain et al., 2012; Schwartz and Reddi, 1979), strontium (Yang et al., 2011)) may be partly responsible for the behaviour of bone precursor cells. These mineral ions have been associated with expansion of bone precursor cells, osteogenic differentiation of marrow-derived MSCs (Barradas et al., 2012; Shih et al., 2014), and optimised non-viral transfection of multiple bone precursors (Choi et al., 2013). 
Common synthetic polymer materials used to form scaffolds for bone healing include poly(alpha-hydroxy esters) (Yu et al., 2010), poly(urethanes) (Guelcher, 2008), poly(propylene fumarate) (Wang et al., 2006), and poly(carbonates) (Kim et al., 2012; Luangphakdy et al., 2013). Thermoplastics such as poly(L-lactide), poly(lactideco-glycolide), poly( $\varepsilon$-caprolactone), poly(propylene fumarate, and poly(urethanes) can be readily processed to allow for interconnected macroporosity, with control over the pore size, structure, and interconnectivity. In addition, these materials can be formed via diverse manufacturing schemes, including casting, injection moulding, and 3-D printing. All have been applied within large bone defects, both as void filler and as an osteoconductive matrix.

Synthetic hydrogels composed of poly(ethylene glycol), poly(propylene fumarate-co-ethylene glycol), and hyaluronic acid have each been used for bone precursor cell culture in vitro or to enhance critical bone defect healing in vivo. In each case the materials can be loaded with bone precursor cells and/or pro-osteogenic molecules to stimulate bone formation (Cartmell, 2009; Salinas and Anseth, 2009). One attractive feature of these hydrogels is their ability to incorporate and deliver controllable dosages of biologically active molecules, including cell adhesion peptides, proteolytically-degradable peptides, ECM proteins, and growth factors. Another feature is the ability to form hydrogels in situ, which opens up new minimallyinvasive clinical opportunities (Behravesh et al., 2003; Kim et al., 2009). Self-assembling hydrogels have been designed to gelate in situ and deliver environments that promote bone formation. For example, peptide amphiphiles can self-assemble into nanofibrous matrices that have been used to nucleate mineral formation (Hartgerink et al., 2001), present peptides for cell adhesion (Webber et al., 2010), or present peptides for growth factor binding (e.g. transforming growth factor (TGF) $\beta$ binding (Shah et al., 2010)).

Some recent examples highlight the potential to combine distinct and complementary synthetic materials to create composite. Investigators have created composites of synthetic polymers and biominerals, taking advantage of the resultant processing benefits of the polymers and the inherent biological activity of the biominerals, resulting in enhanced scaffold compressive modulus, improved osteoconductivity, and greater osseointegration. In one example, 3D printing approaches have been used to create biomineral-coated, $70 \%$ porous poly( $\varepsilon$-caprolactone) scaffolds with mechanical properties that withstand masticatory loads in the mandible, and stimulate bone regeneration as they degrade (Chanchareonsook et al., 2013). Other studies demonstrated that mineral-coated hollow tubes composed of poly( $\varepsilon$-caprolactone) can stimulate bone regeneration in sheep tibia defects (Cipitria et al., 2013) and sheep lumbar spine fusion (Yong et al., 2014). These examples and others suggest that innovative manufacturing of common bone biomaterials can produce a useful toolkit for large bone defect healing.

Furthermore, while we focus this section on synthetic materials, it is noteworthy that a subset of naturally-derived polymers can also be synthetically modified to create natural/synthetic hybrids that stimulate bone formation.
For example, alginate hydrogels can be modified with peptide ligands and used to deliver bone-forming stem cells or osteoinductive growth factors (Drury and Mooney, 2003; Lee and Mooney, 2012). Similarly, fibrin hydrogels can be used as a platform to covalently link pro-osteogenic (Arrighi et al., 2009; Schmoekel et al., 2005) or proangiogenic (Ehrbar et al., 2004) growth factors, which are subsequently delivered during new bone formation. While these materials generally do not match the synthetic and manufacturing adaptability of synthetic materials, they open up the possibility of hybrid approaches that combine the complementary advantages of synthetic and natural components.

Synthetic scaffold design involves a series of design trade-offs, which present inherent challenges for large bone defect healing. For example, scaffolds require optimised mechanical properties for a particular clinical approach, but must also provide adequate porosity for cell infiltration and tissue formation and degradability over a timeframe that scales with the timing of new bone formation (Hollister, 2005). In addition, scaffold design parameters such as $\mu \mathrm{m}$-scale and nm-scale geometry have become increasingly appreciated as critical regulators of osteogenesis. In particular, nm-scale pillars and fibres have been associated with enhanced osteogenic differentiation of bone-forming stem cells in vitro (Dalby et al., 2007), as well as increased osteogenesis in vivo (Ingavle and Leach, 2013). The diversity of existing and emerging parameters that appear to be important for large bone defect healing will call for efficient - and perhaps high throughput screening strategies to identify optimal scaffold materials.

It is noteworthy that one reason why scaffold materials developed to date have been composed of similar base materials relates to the relatively complex regulatory path for novel bone scaffolding materials. Materials comprising new combinations of clinically established base materials typically provide a more rapid route to regulatory approval and clinical applications. In particular, while combinations of existing, FDA approved materials may only require one to demonstrate substantial equivalence to an existing "predicate device", novel scaffold materials often require substantial preclinical studies and one or more clinical studies prior to regulatory approval. The adaptable features of commonly used scaffold materials coupled with the relatively complex regulatory path of novel materials limits innovation.

\section{Drug and growth factor delivery}

A series of small molecule drugs (e.g. bisphosphonates) has been used to treat orthopaedic diseases such as osteoporosis, osteonecrosis, and osteolysis. However, small molecule drugs have not been widely used in large bone defect healing applications. This is perhaps not surprising, as these drug classes are not typically designed to induce formation of new bone tissue in large defects, but rather to regulate the systemic balance between bone resorption and formation. Instead, the focus of large bone defect healing studies has been on local, bone stimulating molecules known to influence natural bone development and healing, such as 
growth factors, hormones, cytokines, and antibodies. The common strategy involves designing a molecule "carrier", which is then combined with an orthopaedic device (Sandor et al., 2013; Warnke et al., 2004). Notable examples include BMP-loaded collagen matrices combined with titanium cages (Boden et al., 2000; Kanayama et al., 2006) or other metallic hardware (Govender et al., 2002). The now extensive clinical experience with BMPs and other bone stimulating molecules suggests critical challenges that must be addressed in the next generation of large bone defect healing strategies. Here, we focus on describing critical challenges to be addressed in next generation of drug delivery strategies, with illustrative examples included.

First, there is a significant pharmacokinetic challenge in delivery of bone stimulating molecules. Recombinant human (rh)BMP2 delivery for instance, is the most prevalent drug delivery strategy used for bone regeneration. While Medtronic's rhBMP-2-releasing device Infuse ${ }^{\text {TM }}$ has achieved a great deal of clinical success in lumbar spine fusion, and widespread use in other clinical indications, it has also been associated with serious side effects (Fu et al., 2013; Faundez et al., 2016). The side effects result in part from the mg-scale quantity of rhBMP-2 delivered, which is multiple orders of magnitude more rhBMP-2 than one might find in a healing bone defect. These side effects could also signal that rhBMP-2 has a narrow therapeutic index, which is a measure of the difference between the clinically effective dosage and the toxic dosage of a drug. As a result, recent studies have focused on controlling the dosage and release kinetics of bone stimulating molecules in order to identify optimal pharmacokinetics for bone healing (King and Krebsbach, 2012; Seeherman and Wozney, 2005). It is not yet clear what combination of total dosage and release kinetics can stimulate bone regeneration while limiting side effects, but it is clear in pre-clinical models that sustained release can decrease the total rhBMP-2 dosage needed to stimulate bone regeneration (Jeon et al., 2008; Kolambkar et al., 2011). Indeed, the signalling mechanisms activated by bone stimulating molecules are typically not unique to bone formation, and molecules are often selected based on their ability to induce heterotopic bone formation. Thus, there is a general need for systematic studies on the influence of localised dosage and release kinetics.

Second, there is a substantial formulation challenge in delivery of bone stimulating molecules. Proteins with significant tertiary structure have a strong tendency to denature, degrade, and/or aggregate under standard physiological conditions, resulting in rapid loss of biological activity. For example, basic fibroblast growth factor (FGF) loses biological activity within minutes in aqueous solution in the absence of heparin (Nguyen et al., 2013). These types of molecules also tend to have narrow therapeutic indices, which results in a need to deliver the molecules in a narrow dosage range. One illustrative example is vascular endothelial growth factor (VEGF), which has been shown to promote blood vessel sprouting within a relatively limited dosage range in vivo (Lee et al., 2000). The ideal approach would be capable of stabilising bone stimulating molecules against inactivation, while also enabling controllable release kinetics from a desirable scaffold material.
In view of these challenges, most common biomaterials used for bone healing are plagued by critical limitations. Elastomeric polymer networks (e.g. hydrogels) allow for molecular transport, which can result in poor bioavailability of a released molecule. Thermoplastics (e.g. poly(alphahydroxy esters)) can be designed to encapsulate and release molecules with controllable dosage and release kinetics, but the biological activity of the released molecules is often significantly compromised due to aggregation, denaturation, and degradation (Zhu et al., 2000). Recent studies with nano-structured materials provide promising solutions to the current challenges. Lipid nanocapsules and mineral capsules have been shown to maintain stability of proteins (Giri et al., 2011). Recent studies indicate that nano-structured biomineral coatings can uniquely stabilise proteins against degradation, while also enabling controllable release kinetics by coating dissolution (Ge et al., 2012; Lu et al., 2009; Suarez-Gonzalez et al., 2012). This direction is promising, as it may address each of the major challenges in growth factor delivery. Further, it is possible to design broadly adaptable biomineral coatings for controllable delivery of peptides, proteins, DNA, cells, and combinations thereof (Choi and Murphy, 2010; Jongpaiboonkit et al., 2009; Lee et al., 2010a; Lee et al., 2010b; Zhang et al., 2010a). In another approach, growth factors have recently been stabilised by heparin-mimetic ligands, which can be covalently linked within hydrogels (Nguyen et al., 2013).

It is important to note that combining bone stimulating molecules with an appropriate scaffold while controlling stability and pharmacokinetics is just one of several inherent challenges in drug delivery. There are unique, complex dynamics in each bone defect environment that make it difficult to define a consistently desirable delivery dose and time scale. The integrity of the soft tissue envelope, status of the periosteum, and age-dependent abundance of bone-forming cell types are among the variables that are not normalised across different patient populations. These complexities make it difficult to arrive at a definitive therapeutic index for scaffold-based drug delivery. In addition, gene expression analyses have shown that over 6,500 genes are differentially regulated during bone healing (Rundle et al., 2006), which suggests a molecularly complex environment in which multiple drugs may be needed to promote optimal formation of bone and other supportive tissue types (e.g. neural, vascular tissues), particularly in large defects. However, the substantial barriers to regulatory approval of devices that deliver a single biologic suggest that carriers for multiple biologics may not be clinically realistic in the foreseeable future. In view of this complexity, there is a clear need to develop adaptable scaffolds that can be used to gain fundamental insights into induced bone formation in a context that can then be efficiently translated to clinical applications.

\section{Cell delivery}

The rationale behind delivery of exogenous cells for bone repair is that addition of appropriate cell types may rescue or potentiate regeneration in cases where 
the natural healing response is compromised or blocked. Only cells can create bone, and therefore transplantation of cells is a logical strategy to overcome recalcitrant healing. Importantly, bone healing is a highly spatially and temporally coordinated process, and therefore it is difficult to recapitulate the normal cascade of events using biomaterials or growth factors alone. Biomaterial-mediated delivery of cells is often used to enhance the engraftment, viability and function of the transplanted cells, and may also be used in conjunction with bioactive factor delivery to mimic physiological healing. Use of a scaffold or matrix typically enhances the mechanical and space-filling function of a transplant, and can provide instructive cues to guide cell function and tissue regeneration. Most cell delivery strategies focus on application of bone forming cells, such as osteoblasts or their precursors (Lee et al., 2009). However, more recent approaches have also targeted concomitant modulation of other physiological processes, such as development of a nourishing vasculature (Rao et al., 2015) or management of the inflammatory response (Loi et al., 2016).

A variety of cell types have been used in bone regeneration strategies. For large bone defects in particular, the use of exogenously supplied cells may be necessary, due to the need for regeneration of larger tissue volumes. In these cases, scaffolds to support cell delivery promote engraftment and provide a space-filling function are often used. The choice of preferred cell type may also depend on the application and age of the patient and in some cases combinations of cells can be applied (Wise et al., 2015). Osteoblasts, the cells that secrete and assemble the ECM of bone, have been delivered in hydrogel biomaterials to enhance bone formation (Alsberg et al., 2001; Burdick and Anseth, 2002); however, issues of immune rejection would require an autologous source for these cells. The difficulties in isolating and expanding osteoblast cells are substantial and make their use in clinics unlikely.

A variety of progenitor cell types have also been examined as cell sources in bone tissue engineering. MSCs are multipotent progenitors that have been shown to differentiate into connective tissue cell types, including osteoblasts (Augello et al., 2010; Rosenbaum et al., 2008), and also have been shown to be potent sources of paracrine signalling factors (Parekkadan and Milwid, 2010) that potentiate healing. Cell surface, or CD (cluster of differentiation) markers, are commonly used to identify MSCs (reviewed in (Harichandan and Buhring, 2011)), yet they should be used with caution. There is increasing evidence that while able to distinguish between mesenchymal and haematopoietic cells, they are not able to define characteristics of stemness (Whitney et al., 2009). However, CD105+ and Stro1+ cells have been proposed as clinically relevant populations. Many groups have published changes in MSC phenotype and loss of mutipotentiality with monolayer expansion (Bruder et al., 1997; Banfi et al., 2000; Bonab et al., 2006). One factor which has been shown to be correlated with maintenance of stemness is leukaemia inhibitory factor 1 (LIF1), the expression of which decreases with monolayer expansion and during differentiation (Whitney et al., 2009).
When considering clinical use of cells, the complications engendered by monolayer expansion provides a significant regulatory hurdle (Bara et al., 2014). This has increasingly led to studies investigating whether freshly isolated, minimally manipulated cells can be used for bone repair. It has been shown that freshly isolated marrow cells can lead to improved bone healing if more than 1,500 colony forming units (CFU) of mesenchymal cells are applied per $\mathrm{cm}^{3}$ of defect (Hernigou et al., 2005). Combining this finding with intra-operative cell harvesting devices provides a potential mechanism by which cell therapy can be readily applied. The use of MSCs offers the possibility of using banked cells, and it has been suggested that allogeneic MSCs are hypoimmunogenic relative to other cell types (Abumaree et al., 2012; Yi and Song, 2012).

MSCs from bone marrow (BMSCs) have been investigated widely in bone tissue engineering (Yousefi et al., 2016). MSCs can also be isolated from adipose tissue, and these cells are often referred to adipose-derived stem cells (ASCs). Obtained through subcutaneous aspiration, adipose tissue presents advantages of easier accessibility (Strioga et al., 2012) with minimal donor site morbidity (Housman et al., 2002) and permits the harvest of larger numbers of MSCs compared to other sources (Fraser et al., 2006). The immunophenotype and other biological characteristics of ASCs are generally similar to marrowderived MSCs, though there are some differences (PachonPena et al., 2011). Indeed, according the cell isolation procedure, a mixed population of cells containing both stromal and endothelial progenitors can also be obtained intraoperatively from the stromal vascular fraction of adipose tissue. These properties make them attractive for bone regeneration (Buschmann et al., 2012; Park et al., 2012). Several attempts to heal large bone defects in animal models have been made using scaffolds loaded with ASCs, but with inconsistent results. Success has been reported for the healing of calvarial defects (Dudas et al., 2006; Follmar et al., 2007), but large segmental defects in long bones do not always heal in the absence of BMP-2 (Hao et al., 2010; Li et al., 2007; Peterson et al., 2005). When the effectiveness of ASCs and BMSCs was compared in a large segmental defect in sheep (Niemeyer et al., 2010) healing was greater with BMSCs. The latter have shown efficacy in one human study (Quarto et al., 2001) and progenitor cells obtained from periosteum were able to regenerate a human phalanx when applied on a coral scaffold (Vacanti et al., 2001).

Totipotent cells sources, such as embryonic stem cells (ESCs) and induced pluripotent stem cells (iPSCs), have been less commonly explored in bone tissue engineering. Culturing ESCs is technically challenging, and the embryonic source is ethically controversial. However, ESCs have recently been used to derive MSCs, which in turn have been applied to bone regeneration (Arpornmaeklong et al., 2009; Kuhn et al., 2014). iPSCs are a newer potential cell source that offer the possibility of generating pluripotent cells from reprogrammed adult somatic cells (Ko and Im, 2014), and recently they have been combined with scaffold materials targeted at bone regeneration (Liu et al., 2013). 
Lately, much work has focused on co-transplantation of multiple cell populations (i.e. osteogenic and angiogenic cell populations) to enhance the bone regenerative processes. Transplanting cells into large defects can create regions that are hypoxic and low in nutrients necessary for cell survival. To accelerate angiogenesis, cells capable of contributing to the formation of a new vascular supply, such as endothelial cells and endothelial progenitor cells (EPC) can be used along with osteogenic cells (Cornejo et al., 2012; Duttenhoefer et al., 2013; Herrmann et al., 2015; Tavassol et al., 2010). Osteogenic and angiogenic cells may communicate with each other to synergistically improve both of these phenotypic processes (Dariima et al., 2013). EPCs are progenitor cells of haematopoietic lineage origin (Masuda and Asahara, 2003) and can be easily isolated from peripheral blood using positive surface marker selection such as CD133 and CD34 (Asahara et al., 1997; Peichev et al., 2000). They show a high proliferation rate compared to mature endothelial cells (Lin et al., 2000).

Several EPC sub-populations can be identified in peripheral blood. Early and late EPCs (also called OEC outgrowth endothelial cells) can be identified by morphological characteristics (Hur et al., 2004; Lin et al., 2000). Circulating EPCs are known to be responsible for post-natal vasculogenesis, and are mobilised into the blood stream from the bone marrow niche (Asahara et al., 1999). Mobilisation is promoted by ischaemia and certain cytokines such as granulocyte colony stimulating factor (G-CSF). Circulating EPCs mobilised by G-CSF have shown efficacy in healing non-unions in a rat model (Mifune et al., 2008) and, when co-administered with autologous bone graft, a small human clinical trial (Kuroda et al., 2014).

Interestingly, signals produced by chondrocytes may also promote the osteogenic response of stem cells (Thompson et al., 2009) and may help recapitulate endochondral ossification when transplanted with osteoblasts (Alsberg et al., 2002).

Several modular approaches to cell delivery are also being investigated. For example, lyophilised solid scaffolds have been developed that have shape memory properties (Thornton et al., 2004). They may be delivered to a defect in a compact form using a minimally invasive approach such as through a catheter, and then a cell suspension can be subsequently delivered to rehydrate them and drive them to expand into a predetermined shape and volume. Additionally, microscale constructs have been engineered, such as hydrogel microspheres containing cells (Rao et al., 2013) or self-assembling cell aggregates (Hildebrandt et al., 2011; Solorio et al., 2012; Dang et al., 2016; Solorio et al., 2015) that can similarly be injected. It is important to recognise that in some cases cell delivery may not even be necessary, if the scaffold itself can present signals capable of recruiting large enough numbers of endogenous host osteogenic cells (Schantz et al., 2007) and/or antiinflammatory or wound healing macrophages (Das et al., 2013)

\section{Vascularisation}

A key challenge in the treatment of large bone defects is the establishment of sufficient vascularisation at the defect site. Because the oxygen delivery required for the survival of cells is usually limited to a diffusion distance of $\sim 150$ $200 \mu \mathrm{m}$ to a neighbouring microvessel (Colton, 1995), the centre of cell seeded constructs rapidly die without the establishment of a blood supply. Accordingly, various vascularisation strategies have been developed in the field of regenerative medicine and tissue engineering (Laschke and Menger, 2012), which may more successfully support the treatment of large bone defects in future clinical practice (Fig. 2). The close physical and biochemical interaction between microvessels and bone cells is essential for bone formation and repair (Carano and Filvaroff, 2003). Many angiogenic growth factors, such as VEGF or FGF, have been shown to promote the differentiation, migration and proliferation of osteoblasts (Carano and Filvaroff, 2003). On the other hand, osteogenic factors, such as BMP-2, stimulate the switch of endothelial cells from a quiescent to an angiogenic phenotype (Finkenzeller et al., 2012).

An important structural determinant for adequate vascularisation is the pore size of scaffolds. It is well recognised that the ideal pore size for the ingrowth of new microvessels ranges between $\sim 200-600 \mu \mathrm{m}$ (Druecke et al., 2004). In this size range, poly(lactic-co-glycolic acid) (PLGA) scaffolds for bone defect repair also display suitable oxygen diffusion, pre-osteoblast cell infiltration, proliferation and survival without losing their mechanical strength (Amini et al., 2012). However, this does not necessarily require that scaffolds should be created with a homogeneous pore size. In fact, sophisticated technologies such as rapid prototyping offer the possibility to fabricate scaffolds with clearly defined porosity levels to ideally promote individual key steps of the bone healing process. Yang et al. developed ceramic scaffolds with sub- $\mu \mathrm{m}$ pores to improve cell/surface interactions, pores of tens of $\mu \mathrm{m}$ to support osteoconduction, and corridors of 100$600 \mu \mathrm{m}$ to stimulate vascularisation (Yang et al., 2006). Finally, the overall three-dimensional architecture of scaffolds has recently been shown to markedly affect their vascularisation.

The vascularisation of bone defects may also be improved by the application of compounds with proangiogenic properties. Of interest, Holstein et al. reported that systemic treatment with the glycoprotein erythropoietin (EPO) is capable of stimulating bone formation, cell proliferation and angiogenesis in a femoral segmental defect model in mice (Holstein et al., 2011). Compared to this systemic approach, the topical application of angiogenic growth factors at the defect site is much more common. For this purpose, the factors may be coated on the surface of solid scaffolds (Sun et al., 2011) or incorporated into drug delivery systems such as microparticles or hydrogels (Geuze et al., 2012; Ishida et al., 2010; Ratanavaraporn et al., 2011). Alternatively, platelet-rich plasma (PRP) may be applied, which represents a rich, autologous source of various growth factors and can easily be isolated from patients under clinical conditions (Lucarelli et al., 2005; Jalowiec et al., 2016; Lippross et al., 2011). In general, it 


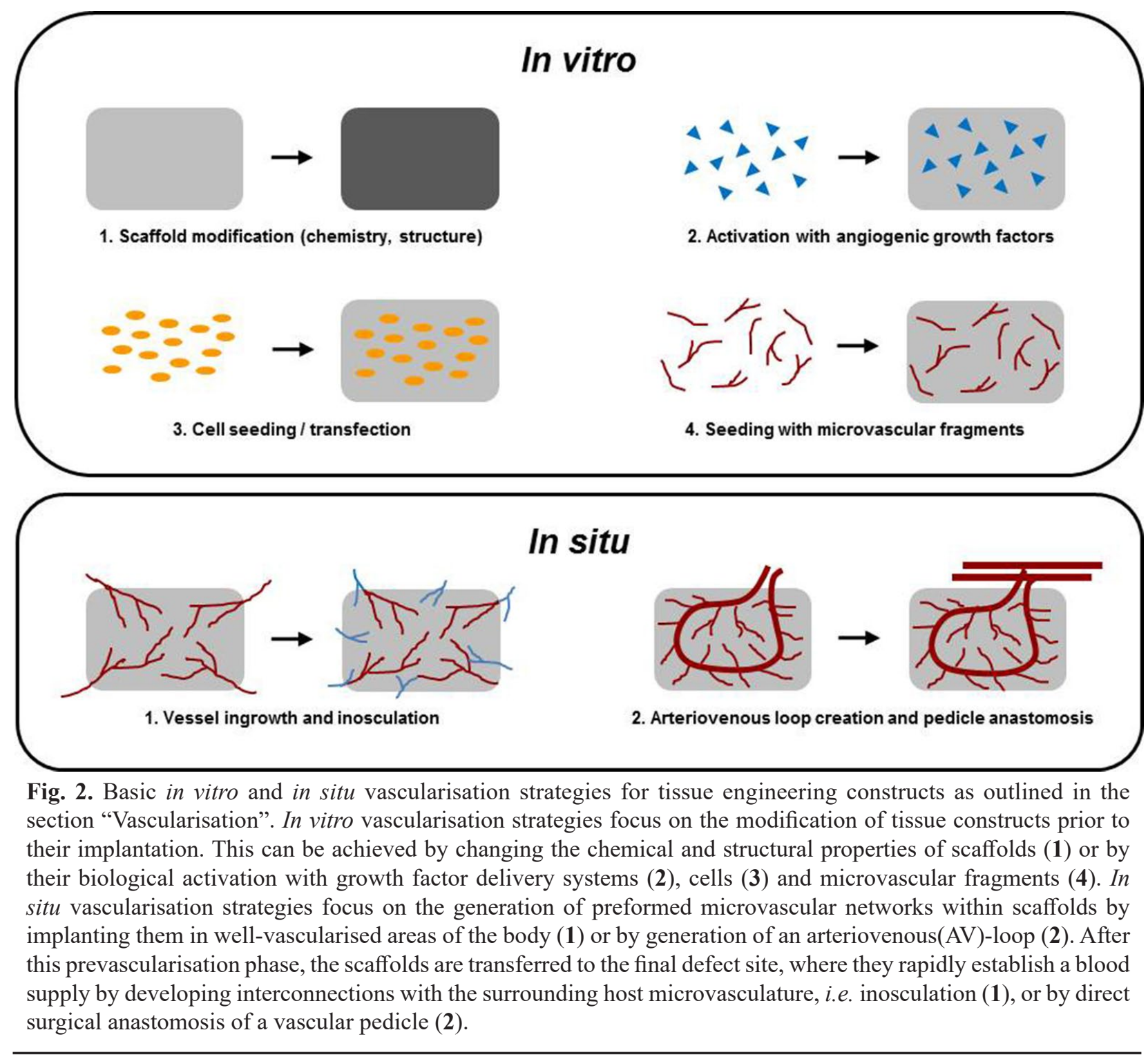

should be noted that the efficacy of the administration of growth factors may be markedly influenced by their release rates and inactivation (Geuze et al., 2012) (see section "Drug and Growth Factors delivery"). Moreover, there is no doubt that a combination of factors support individual stages of bone healing and angiogenesis (Ratanavaraporn et al., 2011; Su et al., 2013). Besides treatment with growth factors, local delivery of miRNA is as a novel possibility to optimise angiogenesis-osteogenesis coupling during bone defect healing. Over-expression of miR-26a in critical-size calvarial bone defect resulted in an improved vascularisation and complete defect healing ( $\mathrm{Li}$ et al., 2013).

There are several possibilities for the generation of microvascular networks within tissue constructs. These include the in vitro seeding and cultivation of scaffolds with vessel-forming cell types (Koike et al., 2004; Wang et $a l ., 2007)$. However, this involves complex cell isolation, seeding, and cultivation procedures, which may not be realisable in clinical practice. Another common strategy to induce vascularisation in bone defect healing is the seeding of appropriate scaffolds with differentiated tissue-specific cells (Cornejo et al., 2012; Tavassol et al., 2010), EPCs
(Seebach et al., 2010) or multipotent stem cells (Maraldi et al., 2013; Zhang et al., 2010b) (see section "Cell delivery"). By this method, the formation of new blood vessels is primarily stimulated by hypoxia-driven cellular release of angiogenic growth factors during engraftment (Schumann et al., 2009). The seeded cells may additionally be genetically modified to guarantee a more continuous growth factor secretion at the defect site (see section "Gene Therapy"). Promising growth factors in bone defect healing include hypoxia-inducible factor-(HIF)-1 $\alpha$ (Zou et al., 2012), VEGF (Geiger et al., 2005; Li et al., 2009b), FGF2 (Guo et al., 2006; Qu et al., 2011), and angiopoietin-1 (Cao et al., 2012a).

An interesting study by Kasper et al. indicates that some of the angiogenic and vasculogenic mechanisms may be additionally regulated by mechanical loading of the cells (Kasper et al., 2007). Using tube formation and spheroid sprouting assays, they found a significant enhancement of angiogenesis by conditioned media from mechanically stimulated compared with unstimulated MSCs. Thus, they concluded that mechanical loading of MSCs results in a paracrine stimulation of blood vessel formation, most likely by the up-regulation of angiogenic growth 
factors including VEGF and FGF. Another determinant for the vascularisation potential of MSCs is their threedimensional arrangement. It was recently demonstrated that polyurethane scaffolds, which are seeded with multicellular MSC spheroids, exhibit a markedly improved vascularisation when compared to control scaffolds seeded with an identical number of individual MSCs (Laschke et al., 2013). Immunohistochemical analyses of the implants revealed that this is due to an enhanced vessel-forming capacity of the three-dimensional MSC spheroids, making them attractive vascularisation units for future tissue engineering applications.

Taken together, all of these studies indicate that major progress has been made in recent years towards establishing novel strategies to promote angiogenesis and vasculogenesis in bone tissue engineering. However, the basic problem of all of these strategies is the fact that blood vessel formation is a time-consuming multi-step process, which cannot be accelerated limitlessly. The growth of newly developing microvessels is usually not faster than $\sim 5 \mu \mathrm{m} / \mathrm{h}$ (Utzinger et al., 2015). Accordingly, complete vascularisation of large bone defects by ingrowth of microvessels from the defect borders takes far too long to guarantee cell survival at the defect site. A promising concept to overcome this problem is the generation of prevascularised tissue constructs that exhibit a functional preformed microvascular network, which connects with the surrounding microvasculature, known as inosculation (Laschke and Menger, 2016).

Alternatively, it is possible to pre-vascularise scaffolds in situ by implanting them in well-vascularised areas of the body to promote the ingrowth of new microvessels (Laschke et al., 2011). Moreover, the incorporation of an arteriovenous loop (AV)-loop, i.e. a ligated artery and vein (Boos et al., 2013), or a vasculature bundle (VB), i.e. a ligated artery and vein, into scaffolds even allows the in situ generation of tissue constructs with a vascular pedicle, which can be surgically anastomosed to the vessels of the defect site. Of interest, Wu et al. found that the VB technique results in a better balance between bone regeneration and scaffold degradation than the AVloop strategy for the prevascularisation of bone constructs consisting of $\beta$-tricalcium phosphate scaffolds and BMSCs (Wu et al., 2015).

Currently, in situ prevascularisation represents the most promising approach to guarantee a sufficient blood supply to large bone constructs in the clinical setting. In fact, Horch et al. recently reported the first successful application of the AV-loop technique in two patients with large bone defects in the radius and tibia (Horch et al., 2014). However, in situ prevascularisation strategies normally bear the disadvantage that they require repetitive surgical interventions for the implantation of scaffolds to the site of prevascularisation, and their removal for final transfer into a defect. To overcome this problem, scaffolds may be seeded in the future with adipose-derived microvascular fragments (Laschke and Menger, 2015a). These microvascular fragments are a randomised mixture of fully functional arteriolar, capillary and venular vessel segments with associated MSCs, which can be easily isolated from adipose tissue by enzymatic digestion
(Laschke and Menger, 2015). After their implantation these fragments survive and exhibit a high angiogenic activity, forming new microvascular networks, which develop interconnections to the microvessels of the host tissue.

\section{Mechanical factors}

Mechanical stability is known to be an important factor for bone healing outcome. Indeed, beside the quality of the implant, a large amount of experimental and clinical evidence confirms that the course of fracture repair can be influenced by mechanical stimuli, and that controlled instability at the fracture site (dynamisation) can deeply affect bone regeneration. However, optimal loading parameters to enhance fracture healing have not yet been entirely defined. There are still many uncertainties concerning the magnitude of the load, the loading timing after fracture, but also the type of loading (e.g. axial, bending). Despite the considerable attention paid to fracture healing and, to some degree, sub-critical size osteotomies, there is very little literature on the effects of the mechanical environment on the healing of large bone defects.

Mechanical stimulation of bone can be classified according to the type of motion applied. Since Goodship and Kenwright (Goodship and Kenwright, 1985), several groups have shown that a cyclic, axial, compressive displacement applied to a diaphysal fracture or osteotomy induces higher healing by the formation of a stronger cartilaginous callus leading to earlier bone bridging (Claes et al., 1998; Wolf et al., 1998; Yamaji et al., 2001).

In certain studies, strains in the range of $5 \%$ and $15 \%$ were shown to be beneficial (Claes and Heigele, 1999; Wolf et al., 1998; Yamaji et al., 2001). In other studies, however, maximum strains of $7 \%$ have been described to be beneficial to the gap bridging (Augat et al., 1998; Claes et al., 1997; Claes et al., 1998), and larger displacement was described as resulting in more fibrous tissue leading to delayed bone union. In a nice experimental set up, Hente (Hente R et al., 1990) looked at the effect of defined strain on new bone formation (Fig. 3). A strain gradient from $0 \%$ to more than $100 \%$ was applied along a fracture gap. Results showed that $0 \%$ strain did not promote callus formation, while strain from $30 \%$ and higher induced massive callus formation but without any evidence of bridging. However, a strain of $5 \%$ in this system was found to be the most efficient to induce solid bridging of the gap.

Another parameter, which is still a point of discussion, is the optimal initiation of stimulation. At the cellular level, it has been shown that mesenchymal cells differentiate toward osteogenic or chondrogenic lineages at early stages of the healing process, depending on the mechanical environment (Le et al., 2001; Thompson et al., 2002). Studies comparing timing of initiation of axial loading in a rat osteotomy model, showed a positive effect of direct post-surgery stimulation (Klein et al., 2003; Weaver et al., 2010). In addition, Weaver also reported a positive effect of a later starting point (10 d post-surgery), while an intermediate time point ( $3 \mathrm{~d}$ ) was not as beneficial. A beneficial effect of a later starting point was also described 


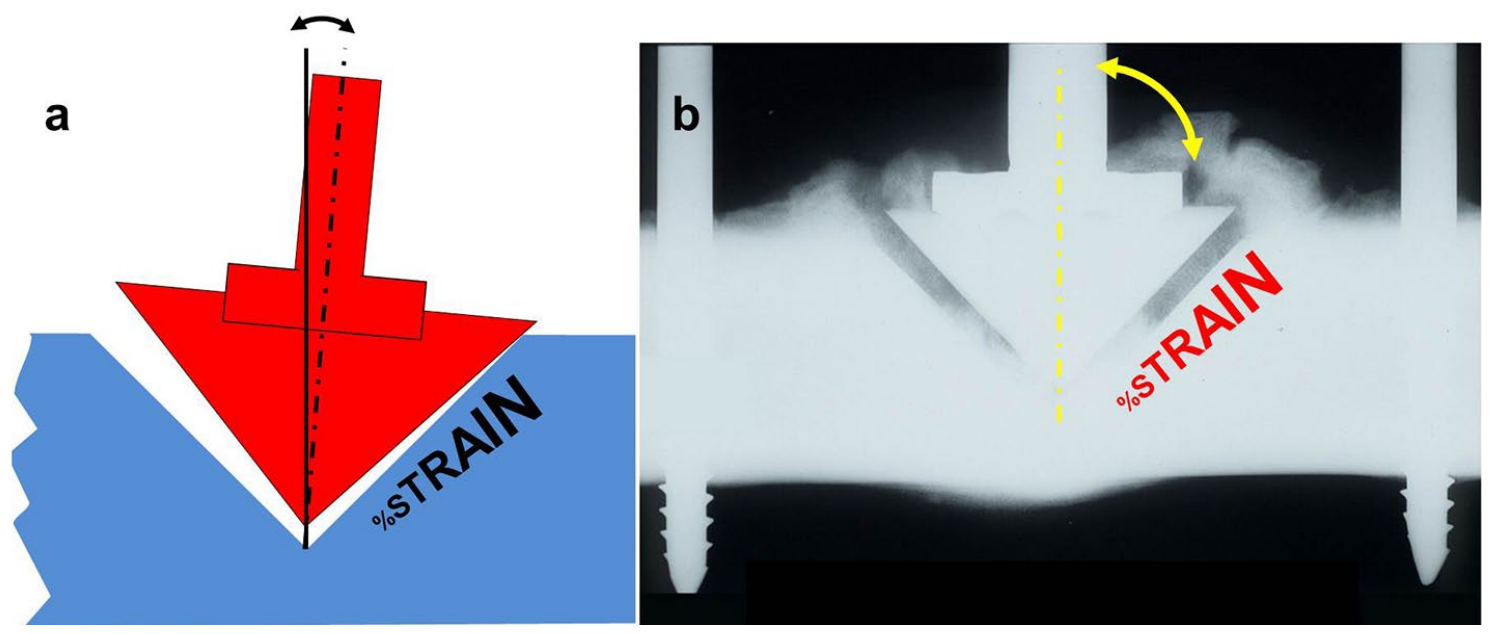

Fig. 3. Effect of strain on callus formation (adapted from (Hente et al., 1990)). (a): schematic representation of the experimental set up. A portion of bone is cyclically tilted along its gap of origin, creating a gradient of strain from 0 (tip of the fragment) to $100 \%$ (top of the fragment). (b): X-ray imaging showing the presence of bone bridging in the lower strain area compared to the higher strain where larger callus formation without bridging was observed.

by others and was explained by the fact that this delay might be favourable to the initiation of neo-vascularisation (Claes et al., 2002; Wallace et al., 1994).

However, while several groups have studied the effect of mechanical stimulation on small defects (1 to $2 \mathrm{~mm}$ osteotomy), only few studies have reported the effect of mechanical loading on a large bone defect. In a critical size goat femur bone defect (filled with demineralised bone and MSCs), treated with either a dynamic intramedullary rod or a static intramedullary rod, an overall better neovascularisation of the implants was seen in the dynamised cases (10\% strain) compared to the rigid fixations (Hou et al., 2010). Callus formation and bone healing was compared in a $5 \mathrm{~mm}$ defect treated with BMP-2, when the defects were stabilised with interchangeable external fixators creating low, medium or high axial stiffness (Glatt et al., 2012). Under constant stiffness, the low stiffness group showed an increased healing rate when compared to the medium or high stiffness groups. While switching at day 14 from low stiffness to a high stiffness fixator (reverse dynamisation), showed by far improved bone healing compared to all other groups. Epari et al. subsequently provided a theoretical basis for these observations (Epari et al., 2013).

Thus a systematic comparison of the three above cited parameters (timing, amplitude and loading type) is still missing. Additionally, studies investigating osteosynthesis devices designed specifically for critical sized defects are lacking. Such studies are needed to provide a clearer view about the effects of mechanical stimulation on the healing of large bone defects.

\section{Additional approaches}

\section{Endochondral bone tissue engineering}

In vitro bone tissue engineering strategies commonly focus on promoting direct osteoblastic differentiation within cell-seeded constructs, mimicking the process of intramembranous ossification. Such engineered tissues often fail to promote bone regeneration following implantation (Lyons et al., 2010), leading to increased interest in endochondral bone tissue engineering strategies (Thompson et al., 2014). This involves the implantation of tissue engineered cartilage in an attempt to recapitulate the normal long bone development process whereby a cartilaginous template becomes hypertrophic, is vascularised, and is ultimately replaced with bone. The logic of this approach is that chondrocytes are better equipped to survive within the nutrient and oxygen deprived environments that exist within a large bone defect (Farrell et al., 2009; Gawlitta et al., 2010). Furthermore, hypertrophic chondrocytes progressing along the endochondral pathway are known to release factors such as VEGF to promote vascularisation of the implanted tissue (Farrell et al., 2009; Gawlitta et al., 2010).

Chondrogenically primed BMSCs also have an inherent tendency to become hypertrophic and undergo endochondral ossification (Farrell et al., 2009; Pelttari et al., 2006; Scotti et al., 2010; Vinardell et al., 2012b). This has motivated the use of cartilaginous constructs engineered using BMSC-seeded scaffolds for bone regeneration. One of the earliest demonstrations of this concept was reported by Huang and colleagues (Huang et al., 2006), who found that cartilage tissue engineered in vitro using BMSCs could be used for carpal bone reconstruction in a rabbit model. More recent studies have provided greater insight into the mechanisms by which chondrogenically differentiated BMSCs promote bone formation in vivo. TGF- $\beta$ typically used to promote chondrogenic differentiation of BMSCs, has been shown to promote the expression not only of genes associated with chondrogenesis and hypertrophy, but also the production of factors critical to vascularisation such as VEGF and matrix metalloproteinases (Farrell et al., 2009; Pelttari et al., 2006). Following implantation, chondrogenically primed 
MSCs have been shown to directly contribute to new bone tissue formation, and also to facilitate the recruitment of host cells capable of further driving osteogenesis (Farrell et al., 2011; Pelttari et al., 2006; Scotti et al., 2010). MSC-seeded scaffolds have also been shown to promote greater vascularisation than osteoblast-seeded scaffolds in vivo by activating an endochondral ossification process and recruiting host-derived CD31+ endothelial cells, followed by a second wave of host derived CD146+ cells that display characteristics of MSCs (Tortelli et al., 2010). Chondrogenically primed MSCs can accelerate the regeneration of critically sized bone defects in small animal models. Cartilage grafts were used to promote regeneration using a murine segmental tibial defect model (Bahney et al., 2014). This study also used lineage tracing experiments to show the regenerate was graft-derived, suggesting the direct transformation of chondrocytes into bone forming cells (Bahney et al., 2014). Finally, it has recently been demonstrated that chondrogenicallyprimed MSC-laden scaffolds support greater repair of critical-sized cranial defects than osteogenically stimulated constructs (Thompson et al., 2016). Taken together, these studies demonstrate the potential of endochondral tissue engineering strategies for orchestrating bone regeneration.

A number of questions still have to be addressed to fully realise the potential of engineered cartilage for large bone defect healing. These include determining the optimal duration of chondrogenic pre-culture for MSCs (Yang et al., 2015), as well as the identification of factors that both promote hypertrophy in vitro and accelerate endochondral bone formation in vivo. MSCs implanted subcutaneously into nude mice have been shown to form bone trabeculae only if they have generated supporting hypertrophic tissue structures prior to implantation (Scotti et al., 2010). More advanced hypertrophic maturation of MSCs in vitro was also found to promote the formation of larger bony tissues in vivo (Scotti et al., 2010). Another challenge involves the identification of suitable biomaterials to support endochondral bone regeneration (Cunniffe et al., 2015), as well as engineering in vitro cultures that facilitate the development of hypertrophic cartilage of sufficient scale to treat large bone defects. MSCs seeded onto collagen-based scaffolds and directed along an endochondral pathway in vitro have been used to generate a scaled-up bone organ in vivo which was found to contain a fully functional haematopoietic compartment (Scotti et al., 2013). Synthetic and natural polymeric scaffolds (Yang et al., 2013; Yang et al., 2015) and various hydrogels (Dickhut et al., 2008) can also potentially be used for engineering scaled-up endochondral bone tissue. An improved understanding of how environmental cues (specific to a bone defect) will regulate endochondral bone regeneration is also required. For example, it has been shown that factors such as a low oxygen environment (Sheehy et al., 2013) as well as certain mechanical cues like compression (Thorpe et al., 2013) and hydrostatic pressure (Vinardell et al., 2012a) can suppress markers of hypertrophy in MSCs. This highlights the need to consider the many factors that contribute to poor outcomes in complex bone fractures and segmental defects when designing novel endochondral bone regeneration strategies.

\section{Gene Therapy}

Although several different osteogenic growth factors show promise as agents of bone healing, their clinical deployment is constrained by delivery problems. In particular, it is not possible to deliver these proteins locally at physiological concentrations in a sustained fashion. With BMPs -2 and -7 , this problem has been addressed clinically by their implantation at very high doses on simple scaffolds. This provides modest clinical efficacy and, at least in the case of BMP-2, provokes a number of adverse events, some serious (Carragee et al., 2011; Faundez et al., 2016) (section "Drug and Growth Factor delivery"). Gene transfer technologies offer to solve these problems. They also remove the concern that preparations of recombinant proteins may contain denatured, and possibly immunogenic, molecules. Moreover, there is evidence that cells respond better to endogenously synthesised growth factors than their recombinant equivalents.

The basic concept is quite simple. A gene, or more usually a cDNA, encoding a protein of interest is delivered by a vector to the site of an osseous defect. This protein is synthesised locally in an endogenous, authentic fashion for as long as the cDNA is present and expressed. By incorporating regulatory elements, it is possible to control both the level and duration of transgene expression. Although most pre-clinical development has focused on delivering cDNAs that encode secreted growth factors, gene transfer is particularly well suited to delivering intracellular proteins, such as transcription factors (Tu et al., 2007), the Lim mineralisation proteins (Lattanzi et al., 2008) and non-coding species of RNA (Levi et al., 2012).

Gene delivery can be accomplished with non-viral and viral vectors. Although non-viral methods are less expensive and generally considered to be safer than viral vectors, they are also much less efficient. Transgene expression is usually low and transient. However, the literature contains examples demonstrating the ability to heal osseous defects in animal models using non-viral gene transfer methods (Kimelman-Bleich et al., 2011; Li et al., 2009a). Nevertheless, most research involves the use of viral vectors which, although more difficult and expensive to prepare, are much more efficient.

Viral vectors that have been explored in the context of bone healing are retrovirus (Rundle et al., 2008), lentivirus (Virk et al., 2011), adenovirus (Baltzer et al., 2000), adenoassociated virus (AAV) (Ito et al., 2005) and baculovirus (Lin et al., 2012). Each has advantages and disadvantages in terms of ease of preparation and use, persistence in the host, immunogenicity, carrying capacity, serotype and so forth. Much effort has been devoted to engineering novel and improved versions of many of these viral vectors, so simple descriptors are increasingly difficult.

Use of viral vectors raises issues of safety, which is a key issue for non-lethal indications such as bone healing. The major safety concern with retroviruses, including lentiviruses, is insertional mutagenesis, which has led to the development of leukaemia in human subjects in a clinical trial for Severe Combined Immunodeficiency Disease (Hacein-Bey-Abina et al., 2003). The major safety issue with adenovirus is the strong immune responses that it generates; these led to gene therapy's first death, in 1999 


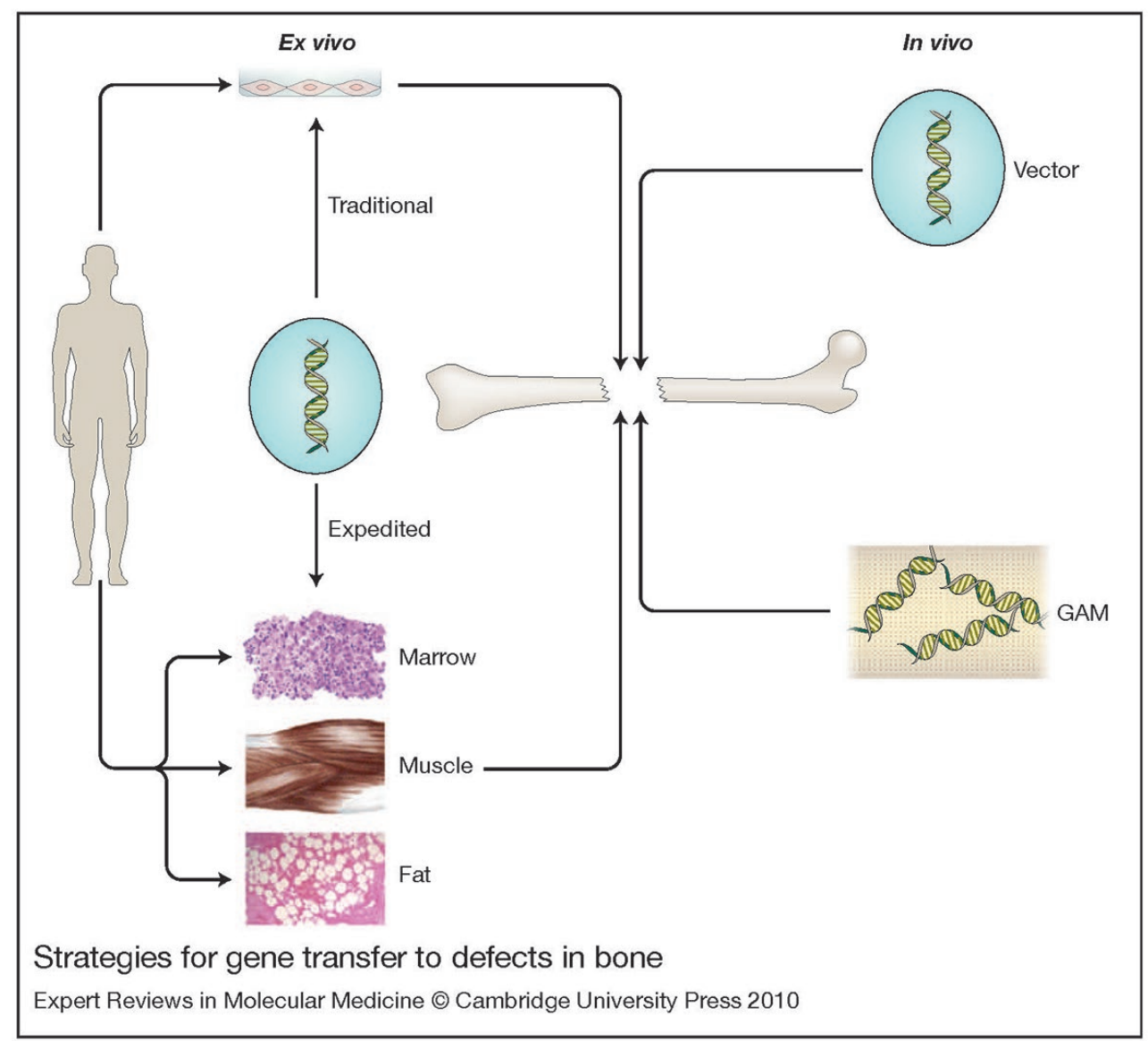

Fig. 4. Current approaches for gene delivery to osseous lesions. There are two general strategies: in vivo (right hand side) and ex vivo (left-hand side). For in vivo gene delivery, the vector is introduced directly into the site of the osseous lesion, either as a free suspension (top right) or incorporated into a gene-activated matrix (GAM) (bottom right). For ex vivo delivery, vectors are not introduced directly into the defect. Instead they are used for the genetic modification of cells, which are subsequently implanted. Traditional ex vivo methods (top left) usually involve the establishment of cell cultures, which are genetically modified in vitro. The modified cells are then introduced into the lesion, often after seeding onto an appropriate scaffold. Expedited ex vivo methods (bottom left) avoid the need for cell culture and scaffolds by genetically modifying tissues such as marrow, muscle and fat, intraoperatively and inserting them into the defect during a single operative session (Evans, 2010).

(Raper et al., 2003). That said, the incidence of severe adverse events in gene therapy trials has been remarkably low and the safety issue is as much one of psychology as biology. Ironically, given recent disclosures concerning the severe adverse events generated by the large amounts of BMP-2 present in Infuse ${ }^{\circledR}$, USA (InductOs, Europe) (Carragee et al., 2011), it is possible to argue that, in this particular application, gene therapy may well be safer than protein therapy.

Most investigators have used cDNAs encoding proteins that promote the osteogenic differentiation of mesenchymal cells. BMP-2 or BMP-7 are popular choices, as the recombinant proteins are already in clinical use. There is also enthusiasm for using cDNAs encoding angiogenic factors such as VEGF (Li et al., 2009b), because osteogenesis is known to have an absolute requirement for angiogenesis (see section "Vascularisation"). Other transgenes of experimental interest include cycloxygenase, which promotes osteogenesis via prostaglandin synthesis (Rundle et al., 2008), and parathyroid hormone 1-34 (Bonadio et al., 1999), among others. Although the choice of osteogenic genes is understandable, long bone fractures mainly heal through the initial phases of cartilaginous callus formation and subsequent endochondral ossification. In recognition of this, there is increasing interest in promoting the endochondral route to healing large bone defects (see section "Endochondral bone tissue engineering"). BMP2 could be a useful transgene in this regard, because it promotes both chondrogenesis (Palmer et al., 2005) and the endochondral differentiation of MSCs (Steinert et al., 2009).

Regardless of the vectors and transgenes that are used, there are two major strategies for their deployment: in vivo and ex vivo. During in vivo delivery the vector is introduced directly into the osseous defect. This has advantages of simplicity, but raises safety concerns. Ex vivo delivery is more cumbersome and expensive, but does not introduce vector into the body and provides the opportunity to deliver both osteoprogenitor cells and osteogenic genes concomitantly to the defect. The considerable cost and complexity of ex vivo gene delivery with autologous cells can be mitigated with allogeneic, universal donor cells, 
or by developing expedited protocols where autologous cells or tissues are removed, genetically modified, and reimplanted in a single operative session (Evans et al., 2007).

Based upon these principles, four main approaches have emerged (Fig. 4) for delivery of genes to osseous lesions: in vivo gene delivery by direct injection or with gene-activated matrices (GAMs), and ex vivo delivery using expanded autologous cells or expedited approaches accomplished intra-operatively.

The direct injection of adenovirus vectors encoding BMP-2 (Baltzer et al., 2000; Betz et al., 2006) or BMP-6 (Bertone et al., 2004; Ishihara et al., 2008) can heal critical size femoral defects in rats, rabbits and horses. However, it is not reliably effective in all animals and generates a strong neutralising immune reaction to the vector. These immune reactions were sufficiently strong to prevent efficacy in large bone defects in sheep (Egermann et al., 2006b), unless the sheep had been treated previously with cortisone, an immunosuppressant (Egermann et al., 2006a). Of concern, immune reactions to human BMP-2 were generated in the sheep model, possibly reflecting the strong adjuvant properties of adenovirus.

GAMs provide an alternative approach. The original GAM comprised a collagenous scaffold impregnated with plasmid DNA encoding BMP-4 (Fang et al., 1996) or the first 34 amino acids of parathyroid hormone (PTH 1-34) (Bonadio et al., 1999), presently used as the drug teriparatide $\left(\right.$ Forteo $\left.^{\circledR}\right)$ to treat osteoporosis. Impressive data were reported in rat and canine models, but further development was hindered by the low levels of transgene expression. GAMs incorporating improved non-viral (Tierney et al., 2012) or viral vectors show more efficient gene transfer and expression in animal models.

Allograft revitalisation is an extension of the GAM principle in which AAV vectors are coated onto allograft bone (Ito et al., 2005). After implantation, host progenitor cells encounter the vector and express transgenes, leading to resorption of the allograft and its replacement with host bone. Success has also been reported when AAV is coated onto poly(epsilon-caprolactone) (Dupont et al., 2012).

Lieberman's group pioneered the ex vivo approach, successfully using an adenovirus vector encoding BMP-2 in conjunction with BMSCs (Lieberman et al., 1999). To expedite matters, they now use buffy coat cells obtained intra-operatively from bone marrow, in conjunction with a lentivirus vector that gives higher and more persistent transgene expression (Virk et al., 2011). Because of concerns about insertional mutagenesis with lentivirus, the inclusion of a suicide gene, to be activated in the event of malignant transformation or other severe adverse event, is being explored (Alaee et al., 2014).

An alternative expedited, ex vivo approach makes use of the remarkable osteogenic properties of muscle, reflected in the high incidence of heterotopic ossification of muscle after blast injuries and joint replacement surgery, as well as in the disease fibrodysplasia ossificans progressiva. The latter occurs as a result of an activating mutation in a BMP receptor, suggesting that a sustained BMP signal efficiently induces bone in muscle. Use of an adenovirus encoding BMP-2 (Ad.BMP-2) provides such as signal.
Musgrave et al. showed that the intra-muscular injection of Ad.BMP-2 induced bone in muscle (Musgrave et al., 1999). This has been adapted in a strategy where biopsies of autologous muscle are transduced with Ad.BMP-2 and implanted into critical sized defects in rats (Evans et al., 2009). Autologous fat is also effective, but less reliably than muscle. Of note, this abbreviated ex vivo procedure eliminated the humoral response to adenovirus (Evans et al., 2009).

Despite a considerable literature, reviewed in references (Evans, 2010; Evans, 2012; Pensak and Lieberman, 2013), reporting successes in healing large bone defects in animal models by gene therapy, it is not used clinically. There are a number of reasons for this, including the need for studies in large animals, which are costly and take a long time. Often, insufficient attention is paid to pharmacology, toxicology and other important matters of this nature. Furthermore, the scientists who undertake the pre-clinical research are often naïve when it comes to the process of research translation, which involves a wide spectrum of expertise, ranging from regulatory issues, to clinical trial design, ethics, and so forth. It is wise to involve individuals with the necessary expertise early in the research programme to forestall subsequent barriers to translation (Madry et al., 2014).

Another constraint to clinical application lies in the simple fact that we do not know how much of a given gene product is needed at which time during the healing process and for how long. Such information would greatly advance the field.

\section{Conclusions}

At a minimum, the regeneration of bone requires the balanced contributions of scaffolds, cells, morphogenetic signals, vascularisation and mechanics. Each of these elements is being studied intensively, and considerable advances have been made in developing new understandings, concepts and information. Because each of these components has many facets, and therefore an even greater number of permutations, there are innumerable theoretical combinations that frustrate any straightforward development of new, osteogenic technologies.

But it is also noteworthy that, despite decades of research in this area using different combinations of the components discussed in this review, we still lack an approved engineered product that gives robust, reliable results in the clinic. It is possible that, given the impossibly large number of permutations of the base components studied for the healing of large, osseous, segmental defects, researchers have not yet arrived at the optimal combination. However, it is also possible that we are missing something. Bone, after all, normally heals by itself, whereas large segmental defects do not. Perhaps we need to go back to the beginning and discover why large segmental defects in otherwise healthy individuals do not heal? Perhaps formulating strategies based upon the way fractures heal naturally is inappropriate?

Regardless of the technologies that actually work reliably in advanced pre-clinical models, the clinical 
development of such technologies is constrained by the regulatory environment that governs their deployment, as well as the financial realities of health care economics. The reality may be that without adequate stratification and identification of patients, complex therapies may not provide the economic benefit to make them viable. As described in this critical review, progress is occurring on several fronts and it should be only a matter of time before patients can benefit from better ways to heal large segmental defects. Achieving this will require interactive, well-funded, sustained consortia including biologists, physical scientists, clinicians, translational scientists, and industrial partners.

\section{Acknowledgements}

The authors acknowledge the support of the AO Foundation in establishing and maintaining their large bone defect healing consortium.

\section{References}

Abumaree M, Al Jumah M, Pace RA, Kalionis B (2012) Immunosuppressive properties of mesenchymal stem cells. Stem Cell Rev 8: 375-392.

Alaee F, Sugiyama O, Virk MS, Tang H, Drissi H, Lichtler AC, Lieberman JR (2014) Suicide gene approach using a dual-expression lentiviral vector to enhance the safety of ex vivo gene therapy for bone repair. Gene Ther 21: 139-147.

Alsberg E, Anderson KW, Albeiruti A, Franceschi RT, Mooney DJ (2001) Cell-interactive alginate hydrogels for bone tissue engineering. J Dent Res 80: 2025-2029.

Alsberg E, Anderson KW, Albeiruti A, Rowley JA, Mooney DJ (2002) Engineering growing tissues. Proc Natl Acad Sci U S A 99: 12025-12030.

Amini AR, Adams DJ, Laurencin CT, Nukavarapu SP (2012) Optimally porous and biomechanically compatible scaffolds for large-area bone regeneration. Tissue Eng Part A 18: 1376-1388.

Arpornmaeklong P, Brown SE, Wang Z, Krebsbach PH (2009) Phenotypic characterisation, osteoblastic differentiation, and bone regeneration capacity of human embryonic stem cell-derived mesenchymal stem cells. Stem Cells Dev 18: 955-968.

Arrighi I, Mark S, Alvisi M, von Rechenber B, Hubbell JA, Schense JC (2009) Bone healing induced by local delivery of an engineered parathyroid hormone prodrug. Biomaterials 30: 1763-1771.

Asahara T, Masuda H, Takahashi T, Kalka C, Pastore C, Silver M, Kearne M, Magner M, Isner JM (1999) Bone marrow origin of endothelial progenitor cells responsible for postnatal vasculogenesis in physiological and pathological neovascularization. Circ Res 85: 221-228.

Asahara T, Murohara T, Sullivan A, Silver M, van der Zee R, Li T, Witzenbichler B, Schatteman G, Isner JM (1997) Isolation of putative progenitor endothelial cells for angiogenesis. Science 275: 964-967.
Augat P, Margevicius K, Simon J, Wolf S, Suger G, Claes L (1998) Local tissue properties in bone healing: influence of size and stability of the osteotomy gap. J Orthop Res 16: 475-481.

Augello A, Kurth TB, De BC (2010) Mesenchymal stem cells: a perspective from in vitro cultures to in vivo migration and niches. Eur Cell Mater 20: 121-133.

Badylak SF, Freytes DO, Gilbert TW (2009) Extracellular matrix as a biological scaffold material: Structure and function. Acta Biomater 5: 1-13.

Bahney CS, Hu DP, Taylor AJ, Ferro F, Britz HM, Hallgrimsson B, Johnstone B, Miclau T, Marcucio RS (2014) Stem cell-derived endochondral cartilage stimulates bone healing by tissue transformation. J Bone Miner Res 29: 1269-1282.

Baltzer AW, Lattermann C, Whalen JD, Wooley P, Weiss K, Grimm M, Ghivizzani SC, Robbins PD, Evans CH (2000) Genetic enhancement of fracture repair: healing of an experimental segmental defect by adenoviral transfer of the BMP-2 gene. Gene Ther 7: 734-739.

Banfi A, Muraglia A, Dozin B, Mastrogiacomo M, Cancedda R, Quarto R (2000) Proliferation kinetics and differentiation potential of ex vivo expanded human bone marrow stromal cells: Implications for their use in cell therapy. Exp Hematol 28: 707-715.

Bara JJ, Richards RG, Alini M, Stoddart MJ (2014) Concise review: Bone marrow-derived mesenchymal stem cells change phenotype following in vitro culture: implications for basic research and the clinic. Stem Cells 32: 1713-1723.

Barradas AM, Fernandes HA, Groen N, Chai YC, Schrooten J, van de Peppel J, van Leeuwen JP, van Blitterswijk CA, de BJ (2012) A calcium-induced signaling cascade leading to osteogenic differentiation of human bone marrow-derived mesenchymal stromal cells. Biomaterials 33: 3205-3215.

Behravesh E, Zygourakis K, Mikos AG (2003) Adhesion and migration of marrow-derived osteoblasts on injectable in situ crosslinkable poly(propylene fumarateco-ethylene glycol)-based hydrogels with a covalently linked RGDS peptide. J Biomed Mater Res A 65: 260-270.

Bertone AL, Pittman DD, Bouxsein ML, Li J, Clancy B, Seeherman HJ (2004) Adenoviral-mediated transfer of human BMP-6 gene accelerates healing in a rabbit ulnar osteotomy model. J Orthop Res 22: 1261-1270.

Betz OB, Betz VM, Nazarian A, Pilapil CG, Vrahas MS, Bouxsein ML, Gerstenfeld LC, Einhorn TA, Evans $\mathrm{CH}$ (2006) Direct percutaneous gene delivery to enhance healing of segmental bone defects. J Bone Joint Surg Am 88: $355-365$.

Boden SD, Zdeblick TA, Sandhu HS, Heim SE (2000) The use of rhBMP-2 in interbody fusion cages. Definitive evidence of osteoinduction in humans: a preliminary report. Spine (Phila Pa 1976) 25: 376-381.

Bonab MM, Alimoghaddam K, Talebian F, Ghaffari SH, Ghavamzadeh A, Nikbin B (2006) Aging of mesenchymal stem cell in vitro. BMC Cell Biol 7: 14.

Bonadio J, Smiley E, Patil P, Goldstein S (1999) Localized, direct plasmid gene delivery in vivo: prolonged therapy results in reproducible tissue regeneration. Nat Med 5: 753-759. 
Boos AM, Loew JS, Weigand A, Deschler G, Klumpp D, Arkudas A, Bleiziffer O, Gulle H, Kneser U, Horch RE, Beier JP (2013) Engineering axially vascularized bone in the sheep arteriovenous-loop model. J Tissue Eng Regen Med 7: 654-664.

Bruder SP, Jaiswal N, Haynesworth SE (1997) Growth kinetics, self-renewal, and the osteogenic potential of purified human mesenchymal stem cells during extensive subcultivation and following cryopreservation. J Cell Biochem 64: 278-294.

Burdick JA, Anseth KS (2002) Photoencapsulation of osteoblasts in injectable RGD-modified PEG hydrogels for bone tissue engineering. Biomaterials 23: 4315-4323.

Buschmann J, Harter L, Gao S, Hemmi S, Welti M, Hild N, Schneider OD, Stark WJ, Lindenblatt N, Werner CM, Wanner GA, Calcagni M (2012) Tissue engineered bone grafts based on biomimetic nanocomposite PLGA/ amorphous calcium phosphate scaffold and human adiposederived stem cells. Injury 43: 1689-1697.

Cao L, Liu X, Liu S, Jiang Y, Zhang X, Zhang C, Zeng B (2012a) Experimental repair of segmental bone defects in rabbits by angiopoietin- 1 gene transfected MSCs seeded on porous beta-TCP scaffolds. J Biomed Mater Res B Appl Biomater 100: 1229-1236.

Cao X, Deng W, Wei Y, Yang Y, Su W, Wei Y, Xu X, Yu J (2012b) Incorporating pTGF-beta 1/calcium phosphate nanoparticles with fibronectin into 3-dimensional collagen/ chitosan scaffolds: efficient, sustained gene delivery to stem cells for chondrogenic differentiation. Eur Cell Mater 23: 81-93.

Carano RA, Filvaroff EH (2003) Angiogenesis and bone repair. Drug Discov Today 8: 980-989.

Carragee EJ, Mitsunaga KA, Hurwitz EL, Scuderi GJ (2011) Retrograde ejaculation after anterior lumbar interbody fusion using rhBMP-2: a cohort controlled study. Spine J 11: 511-516.

Cartmell S (2009) Controlled release scaffolds for bone tissue engineering. J Pharm Sci 98: 430-441.

Chanchareonsook N, Tideman H, Feinberg SE, Hollister SJ, Jongpaiboonkit L, Kin L, Jansen JA (2013) Subcutaneous tissue response to titanium, poly(epsiloncaprolactone), and carbonate-substituted hydroxyapatitecoated poly(epsilon-caprolactone) plates: a rabbit study. J Biomed Mater Res A 101: 2258-2266.

Chen L, Zhu C, Fan D, Liu B, Ma X, Duan Z, Zhou Y (2011) A human-like collagen/chitosan electrospun nanofibrous scaffold from aqueous solution: electrospun mechanism and biocompatibility. J Biomed Mater Res A 99: 395-409.

Cheng CW, Solorio LD, Alsberg E (2014) Decellularized tissue and cell-derived extracellular matrices as scaffolds for orthopaedic tissue engineering. Biotechnol Adv 32: 462-484.

Choi S, Murphy WL (2010) Sustained plasmid DNA release from dissolving mineral coatings. Acta Biomater 6: 3426-3435.

Choi S, Yu X, Jongpaiboonkit L, Hollister SJ, Murphy WL (2013) Inorganic coatings for optimized non-viral transfection of stem cells. Sci Rep 3: 1567.

Chou YF, Huang W, Dunn JC, Miller TA, Wu BM (2005) The effect of biomimetic apatite structure on osteoblast viability, proliferation, and gene expression. Biomaterials 26: 285-295.

Chung YI, Ahn KM, Jeon SH, Lee SY, Lee JH, Tae G (2007) Enhanced bone regeneration with BMP-2 loaded functional nanoparticle-hydrogel complex. J Control Release 121: 91-99.

Cipitria A, Reichert JC, Epari DR, Saifzadeh S, Berner A, Schell H, Mehta M, Schuetz MA, Duda GN, Hutmacher DW (2013) Polycaprolactone scaffold and reduced rhBMP-7 dose for the regeneration of critical-sized defects in sheep tibiae. Biomaterials 34: 9960-9968.

Claes L, Augat P, Suger G, Wilke HJ (1997) Influence of size and stability of the osteotomy gap on the success of fracture healing. J Orthop Res 15: 577-584.

Claes L, Eckert-Hubner K, Augat P (2002) The effect of mechanical stability on local vascularization and tissue differentiation in callus healing. J Orthop Res 20: 10991105.

Claes LE, Heigele CA (1999) Magnitudes of local stress and strain along bony surfaces predict the course and type of fracture healing. J Biomech 32: 255-266.

Claes LE, Heigele CA, Neidlinger-Wilke C, Kaspar D, Seidl W, Margevicius KJ, Augat P (1998) Effects of mechanical factors on the fracture healing process. Clin Orthop Relat Res 355 Suppl: S132-S147.

Colton CK (1995) Implantable biohybrid artificial organs. Cell Transplant 4: 415-436.

Cornejo A, Sahar DE, Stephenson SM, Chang S, Nguyen S, Guda T, Wenke JC, Vasquez A, Michalek JE, Sharma R, Krishnegowda NK, Wang HT (2012) Effect of adipose tissue-derived osteogenic and endothelial cells on bone allograft osteogenesis and vascularization in criticalsized calvarial defects. Tissue Eng Part A 18: 1552-1561.

Costa-Pinto AR, Reis RL, Neves NM (2011) Scaffolds based bone tissue engineering: the role of chitosan. Tissue Eng Part B Rev 17: 331-347.

Cunniffe GM, Vinardell T, Thompson EM, Daly AC, Matsiko A, O’Brien FJ, Kelly DJ (2015) Chondrogenically primed mesenchymal stem cells-seeded alginate hydrogels promote early bone formation in critically-sized defects. European Polymer Journal 72: 464-472.

Curtin CM, Cunniffe GM, Lyons FG, Bessho K, Dickson GR, Duffy GP, O’Brien FJ (2012) Innovative collagen nano-hydroxyapatite scaffolds offer a highly efficient non-viral gene delivery platform for stem cellmediated bone formation. Adv Mater 24: 749-754.

d'Aquino R, De Rosa A, Lanza V, Tirino V, Laino L, Graziano A, Desiderio V, Laino G, Papaccio G (2009) Human mandible bone defect repair by the grafting of dental pulp stem/progenitor cells and collagen sponge biocomplexes. Eur Cell Mater 18: 75-83.

Dalby MJ, Gadegaard N, Tare R, Andar A, Riehle MO, Herzyk P, Wilkinson CD, Oreffo RO (2007) The control of human mesenchymal cell differentiation using nanoscale symmetry and disorder. Nat Mater 6: 997-1003.

Dang PN, Dwivedi N, Phillips LM, Yu X, Herberg S, Bowerman C, Solorio LD, Murphy WL, Alsberg E (2016) Controlled dual growth factor delivery from microparticles incorporated within human bone marrowderived mesenchymal stem cell aggregates for enhanced 
bone tissue engineering via endochondral ossification. Stem Cells Transl Med 5: 206-217.

Dariima T, Jin GZ, Lee EJ, Wall IB, Kim HW (2013) Cooperation between osteoblastic cells and endothelial cells enhances their phenotypic responses and improves osteoblast function. Biotechnol Lett 35: 1135-1143.

Das A, Segar CE, Hughley BB, Bowers DT, Botchwey EA (2013) The promotion of mandibular defect healing by the targeting of S1P receptors and the recruitment of alternatively activated macrophages. Biomaterials 34: 9853-9862.

Datta N, Holtorf HL, Sikavitsas VI, Jansen JA, Mikos AG (2005) Effect of bone extracellular matrix synthesized in vitro on the osteoblastic differentiation of marrow stromal cells. Biomaterials 26: 971-977.

Di Martino A, Sittinger M, Risbud MV (2005) Chitosan: a versatile biopolymer for orthopaedic tissueengineering. Biomaterials 26: 5983-5990.

Dickhut A, Gottwald E, Steck E, Heisel C, Richter W (2008) Chondrogenesis of mesenchymal stem cells in gel-like biomaterials in vitro and in vivo. Front Biosci 13 4517-4528.

Druecke D, Langer S, Lamme E, Pieper J, Ugarkovic M, Steinau HU, Homann HH (2004) Neovascularization of poly(ether ester) block-copolymer scaffolds in vivo: longterm investigations using intravital fluorescent microscopy. J Biomed Mater Res A 68: 10-18.

Drury JL, Mooney DJ (2003) Hydrogels for tissue engineering: scaffold design variables and applications. Biomaterials 24: 4337-4351.

Dudas JR, Marra KG, Cooper GM, Penascino VM, Mooney MP, Jiang S, Rubin JP, Losee JE (2006) The osteogenic potential of adipose-derived stem cells for the repair of rabbit calvarial defects. Ann Plast Surg 56: 543548.

Dupont KM, Boerckel JD, Stevens HY, Diab T, Kolambkar YM, Takahata M, Schwarz EM, Guldberg RE (2012) Synthetic scaffold coating with adeno-associated virus encoding BMP2 to promote endogenous bone repair. Cell Tissue Res 347: 575-588.

Duttenhoefer F, Lara de Freitas R, Meury T, Loibl M, Benneker LM, Richards RG, Alini M, Verrier S (2013) 3D scaffolds co-seeded with human endothelial progenitor and mesenchymal stem cells: evidence of prevascularisation within 7 days. Eur Cell Mater 26: 49-64.

Egermann M, Baltzer AW, Adamaszek S, Evans C, Robbins P, Schneider E, Lill CA (2006a) Direct adenoviral transfer of bone morphogenetic protein- 2 cDNA enhances fracture healing in osteoporotic sheep. Hum Gene Ther 17: 507-517.

Egermann M, Lill CA, Griesbeck K, Evans CH, Robbins PD, Schneider E, Baltzer AW (2006b) Effect of BMP-2 gene transfer on bone healing in sheep. Gene Ther 13: $1290-1299$.

Ehrbar M, Djonov VG, Schnell C, Tschanz SA, Martiny-Baron G, Schenk U, Wood J, Burri PH, Hubbell JA, Zisch AH (2004) Cell-demanded liberation of VEGF121 from fibrin implants induces local and controlled blood vessel growth. Circ Res 94: 1124-1132.
Epari DR, Wehner T, Ignatius A, Schuetz MA, Claes LE (2013) A case for optimising fracture healing through inverse dynamization. Med Hypotheses 81: 225-227.

Evans CH (2010) Gene therapy for bone healing. Expert Rev Mol Med 12: e18.

Evans CH (2012) Gene delivery to bone. Adv Drug Deliv Rev 64: 1331-1340.

Evans CH, Liu FJ, Glatt V, Hoyland JA, Kirker-Head C, Walsh A, Betz O, Wells JW, Betz V, Porter RM, Saad FA, Gerstenfeld LC, Einhorn TA, Harris MB, Vrahas MS (2009) Use of genetically modified muscle and fat grafts to repair defects in bone and cartilage. Eur Cell Mater 18: 96-111.

Evans CH, Palmer GD, Pascher A, Porter R, Kwong FN, Gouze E, Gouze JN, Liu F, Steinert A, Betz O, Betz V, Vrahas M, Ghivizzani SC (2007) Facilitated endogenous repair: making tissue engineering simple, practical, and economical. Tissue Eng 13: 1987-1993.

Fang J, Zhu YY, Smiley E, Bonadio J, Rouleau JP, Goldstein SA, McCauley LK, Davidson BL, Roessler BJ (1996) Stimulation of new bone formation by direct transfer of osteogenic plasmid genes. Proc Natl Acad Sci U S A 93: 5753-5758.

Farrell E, Both SK, Odorfer KI, Koevoet W, Kops N, O'Brien FJ, Baatenburg de Jong RJ, Verhaar JA, Cuijpers V, Jansen J, Erben RG, van Osch GJ (2011) In-vivo generation of bone via endochondral ossification by in-vitro chondrogenic priming of adult human and rat mesenchymal stem cells. BMC Musculoskelet Disord 12: 31.

Farrell E, van der Jagt OP, Koevoet W, Kops N, van Manen CJ, Hellingman CA, Jahr H, O'Brien FJ, Verhaar JA, Weinans H, van Osch GJ (2009) Chondrogenic priming of human bone marrow stromal cells: a better route to bone repair? Tissue Eng Part C Methods 15: 285-295.

Faundez A, Tournier C, Garcia M, Aunoble S, Le Huec JC (2016) Bone morphogenetic protein use in spine surgery-complications and outcomes: a systematic review. Int Orthop 40: 1309-1319.

Ferreira AM, Gentile P, Chiono V, Ciardelli G (2012) Collagen for bone tissue regeneration. Acta Biomater 8: 3191-3200.

Finkenzeller G, Hager S, Stark GB (2012) Effects of bone morphogenetic protein 2 on human umbilical vein endothelial cells. Microvasc Res 84: 81-85.

Follmar KE, Prichard HL, Decroos FC, Wang HT, Levin LS, Klitzman B, Olbrich KC, Erdmann D (2007) Combined bone allograft and adipose-derived stem cell autograft in a rabbit model. Ann Plast Surg 58: 561-565.

Fraser JK, Wulur I, Alfonso Z, Hedrick MH (2006) Fat tissue: an underappreciated source of stem cells for biotechnology. Trends Biotechnol 24: 150-154.

Fu R, Selph S, McDonagh M, Peterson K, Tiwari A, Chou R, Helfand M (2013) Effectiveness and harms of recombinant human bone morphogenetic protein- 2 in spine fusion: a systematic review and meta-analysis. Ann Intern Med 158: 890-902.

Gawlitta D, Farrell E, Malda J, Creemers LB, Alblas J, Dhert WJ (2010) Modulating endochondral ossification of multipotent stromal cells for bone regeneration. Tissue Eng Part B Rev 16: 385-395. 
Ge J, Lei J, Zare RN (2012) Protein-inorganic hybrid nanoflowers. Nat Nanotechnol 7: 428-432.

Geiger F, Bertram H, Berger I, Lorenz H, Wall O, Eckhardt C, Simank HG, Richter W (2005) Vascular endothelial growth factor gene-activated matrix (VEGF165GAM) enhances osteogenesis and angiogenesis in large segmental bone defects. J Bone Miner Res 20: 2028-2035.

Geiger M, Li RH, Friess W (2003) Collagen sponges for bone regeneration with rhBMP-2. Adv Drug Deliv Rev 55: 1613-1629.

Geuze RE, Theyse LF, Kempen DH, Hazewinkel HA, Kraak HY, Oner FC, Dhert WJ, Alblas J (2012) A differential effect of bone morphogenetic protein-2 and vascular endothelial growth factor release timing on osteogenesis at ectopic and orthotopic sites in a largeanimal model. Tissue Eng Part A 18: 2052-2062.

Giannoudis PV, Einhorn TA, Marsh D (2007) Fracture healing: the diamond concept. Injury 38 Suppl 4: S3-S6.

Gibbs DM, Black CR, Dawson JI, Oreffo RO (2014) A review of hydrogel use in fracture healing and bone regeneration. J Tissue Eng Regen Med 10: 187-198.

Giri J, Li WJ, Tuan RS, Cicerone MT (2011) Stabilization of proteins by nanoencapsulation in sugarglass for tissue engineering and drug delivery applications. Adv Mater 23: 4861-4867.

Glatt V, Miller M, Ivkovic A, Liu F, Parry N, Griffin D, Vrahas M, Evans C (2012) Improved healing of large segmental defects in the rat femur by reverse dynamization in the presence of bone morphogenetic protein-2. J Bone Joint Surg Am 94: 2063-2073.

Gleeson JP, Plunkett NA, O’Brien FJ (2010) Addition of hydroxyapatite improves stiffness, interconnectivity and osteogenic potential of a highly porous collagen-based scaffold for bone tissue regeneration. Eur Cell Mater 20: 218-230.

Goncalves RM, Antunes JC, Barbosa MA (2012) Mesenchymal stem cell recruitment by stromal derived factor-1-delivery systems based on chitosan/poly(gammaglutamic acid) polyelectrolyte complexes. Eur Cell Mater 23: 249-260.

Goodship AE, Kenwright J (1985) The influence of induced micromovement upon the healing of experimental tibial fractures. J Bone Joint Surg Br 67: 650-655.

Govender S, Csimma C, Genant HK, Valentin-Opran A, Amit Y, Arbel R, Aro H, Atar D, Bishay M, Borner MG, Chiron P, Choong P, Cinats J, Courtenay B, Feibel R, Geulette B, Gravel C, Haas N, Raschke M, Hammacher E, van der Velde D, Hardy P, Holt M, Josten C, Ketterl RL, Lindeque B, Lob G, Mathevon H, McCoy G, Marsh D, Miller R, Munting E, Oevre S, Nordsletten L, Patel A, Pohl A, Rennie W, Reynders P, Rommens PM, Rondia J, Rossouw WC, Daneel PJ, Ruff S, Ruter A, Santavirta S, Schildhauer TA, Gekle C, Schnettler R, Segal D, Seiler H, Snowdowne RB, Stapert J, Taglang G, Verdonk R, Vogels L, Weckbach A, Wentzensen A, Wisniewski T (2002) Recombinant human bone morphogenetic protein-2 for treatment of open tibial fractures: a prospective, controlled, randomized study of four hundred and fifty patients. J Bone Joint Surg Am 84: 2123-2134.
Gruskin E, Doll BA, Futrell FW, Schmitz JP, Hollinger JO (2012) Demineralized bone matrix in bone repair: history and use. Adv Drug Deliv Rev 64: 1063-1077.

Guelcher SA (2008) Biodegradable polyurethanes: synthesis and applications in regenerative medicine. Tissue Eng Part B Rev 14: 3-17.

Guo X, Zheng Q, Kulbatski I, Yuan Q, Yang S, Shao Z, Wang H, Xiao B, Pan Z, Tang S (2006) Bone regeneration with active angiogenesis by basic fibroblast growth factor gene transfected mesenchymal stem cells seeded on porous beta-TCP ceramic scaffolds. Biomed Mater 1: 93-99.

Hacein-Bey-Abina S, Von Kalle C, Schmidt M, McCormack MP, Wulffraat N, Leboulch P, Lim A, Osborne CS, Pawliuk R, Morillon E, Sorensen R, Forster A, Fraser P, Cohen JI, de Saint Basile G, Alexander I, Wintergerst U, Frebourg T, Aurias A, Stoppa-Lyonnet D, Romana S, Radford-Weiss I, Gross F, Valensi F, Delabesse E, Macintyre E, Sigaux F, Soulier J, Leiva LE, Wissler M, Prinz C, Rabbitts TH, Le Deist F, Fischer A, Cavazzana-Calvo M (2003) LMO2-associated clonal T cell proliferation in two patients after gene therapy for SCID-X1. Science 302: 415-419.

Hao W, Dong J, Jiang M, Wu J, Cui F, Zhou D (2010) Enhanced bone formation in large segmental radial defects by combining adipose-derived stem cells expressing bone morphogenetic protein 2 with nHA/RHLC/PLA scaffold. Int Orthop 34: 1341-1349.

Harichandan A, Buhring HJ (2011) Prospective isolation of human MSC. Best Pract Res Clin Haematol 24: 25-36.

Hartgerink JD, Beniash E, Stupp SI (2001) Selfassembly and mineralization of peptide-amphiphile nanofibers. Science 294: 1684-1688.

Heinemann C, Heinemann S, Bernhardt A, Lode A, Worch H, Hanke T (2010) In vitro osteoclastogenesis on textile chitosan scaffold. Eur Cell Mater 19: 96-106.

Hente R, Cheal E, Perren S (1990) Tissue response to controlled interfragmentary strain gradients in fracture healing. In: 2nd Conference of the International Society for Fracture Repair. ed. E.Y.S Chao, Mayo Clinic, 6-8 September, p148.

Hernigou P, Poignard A, Beaujean F, Rouard H (2005) Percutaneous autologous bone-marrow grafting for nonunions. Influence of the number and concentration of progenitor cells. J Bone Joint Surg Am 87: 1430-1437.

Herrmann M, Laschke MW, Alini M, Scherberich A, Verrier S (2015) Vascularization, survival and functionality of tissue engineered constructs. In: Tissue Engineering, 2nd Edition. Elsevier, Chapter 14, p471-496.

Hildebrandt C, Buth H, Thielecke H (2011) A scaffoldfree in vitro model for osteogenesis of human mesenchymal stem cells. Tissue Cell 43: 91-100.

Hollister SJ (2005) Porous scaffold design for tissue engineering. Nat Mater 4: 518-524.

Holstein JH, Orth M, Scheuer C, Tami A, Becker SC, Garcia P, Histing T, Morsdorf P, Klein M, Pohlemann T, Menger MD (2011) Erythropoietin stimulates bone formation, cell proliferation, and angiogenesis in a femoral segmental defect model in mice. Bone 49: 1037-1045. 
Horch RE, Beier JP, Kneser U, Arkudas A (2014) Successful human long-term application of in situ bone tissue engineering. J Cell Mol Med 18: 1478-1485.

Hosseinkhani H, Hosseinkhani M, Tian F, Kobayashi H, Tabata Y (2006) Ectopic bone formation in collagen sponge self-assembled peptide-amphiphile nanofibers hybrid scaffold in a perfusion culture bioreactor. Biomaterials 27: 5089-5098.

Hou T, Li Q, Luo F, Xu J, Xie Z, Wu X, Zhu C (2010) Controlled dynamization to enhance reconstruction capacity of tissue-engineered bone in healing critically sized bone defects: an in vivo study in goats. Tissue Eng Part A 16: 201-212.

Housman TS, Lawrence N, Mellen BG, George MN, Filippo JS, Cerveny KA, DeMarco M, Feldman SR, Fleischer AB (2002) The safety of liposuction: results of a national survey. Dermatol Surg 28: 971-978.

Huang JI, Durbhakula MM, Angele P, Johnstone B, Yoo JU (2006) Lunate arthroplasty with autologous mesenchymal stem cells in a rabbit model. J Bone Joint Surg Am 88: 744-752.

Huang L, Nagapudi K, Apkarian RP, Chaikof EL (2001) Engineered collagen-PEO nanofibers and fabrics. J Biomater Sci Polym Ed 12: 979-993.

Hur J, Yoon CH, Kim HS, Choi JH, Kang HJ, Hwang KK, Oh BH, Lee MM, Park YB (2004) Characterization of two types of endothelial progenitor cells and their different contributions to neovasculogenesis. Arterioscler Thromb Vasc Biol 24: 288-293.

Hussain A, Bessho K, Takahashi K, Tabata Y (2012) Magnesium calcium phosphate as a novel component enhances mechanical/physical properties of gelatin scaffold and osteogenic differentiation of bone marrow mesenchymal stem cells. Tissue Eng Part A 18: 768-774.

Ingavle GC, Leach JK (2013) Advancements in electrospinning of polymeric nanofibrous scaffolds for tissue engineering. Tissue Eng Part B Rev 20: 277-293.

Ishida K, Matsumoto T, Sasaki K, Mifune Y, Tei K, Kubo S, Matsushita T, Takayama K, Akisue T, Tabata Y, Kurosaka M, Kuroda R (2010) Bone regeneration properties of granulocyte colony-stimulating factor via neovascularization and osteogenesis. Tissue Eng Part A 16: 3271-3284.

Ishihara A, Shields KM, Litsky AS, Mattoon JS, Weisbrode SE, Bartlett JS, Bertone AL (2008) Osteogenic gene regulation and relative acceleration of healing by adenoviral-mediated transfer of human BMP-2 or -6 in equine osteotomy and ostectomy models. J Orthop Res 26: 764-771.

Ito H, Koefoed M, Tiyapatanaputi P, Gromov K, Goater JJ, Carmouche J, Zhang X, Rubery PT, Rabinowitz J, Samulski RJ, Nakamura T, Soballe K, O'Keefe RJ, Boyce BF, Schwarz EM (2005) Remodeling of cortical bone allografts mediated by adherent $r A A V-R A N K L$ and VEGF gene therapy. Nat Med 11: 291-297.

Jalowiec JM, D'Este M, Bara JJ, Denom J, Menzel U, Alini M, Verrier S, Herrmann M (2016) An in vitro investigation of platelet-rich plasma-gel as a cell and growth factor delivery vehicle for tissue engineering. Tissue Eng Part C Methods 22: 49-58.
Jeon O, Bouhadir KH, Mansour JM, Alsberg E (2009) Photocrosslinked alginate hydrogels with tunable biodegradation rates and mechanical properties. Biomaterials 30: 2724-2734.

Jeon O, Song SJ, Yang HS, Bhang SH, Kang SW, Sung MA, Lee JH, Kim BS (2008) Long-term delivery enhances in vivo osteogenic efficacy of bone morphogenetic protein-2 compared to short-term delivery. Biochem Biophys Res Commun 369: 774-780.

Jongpaiboonkit L, Franklin-Ford T, Murphy WL (2009) Growth of hydroxyapatite coatings on biodegradable polymer microspheres. ACS Appl Mater Interfaces 1: 1504-1511.

Kanayama M, Hashimoto T, Shigenobu K, Yamane S, Bauer TW, Togawa D (2006) A prospective randomized study of posterolateral lumbar fusion using osteogenic protein-1 (OP-1) versus local autograft with ceramic bone substitute: emphasis of surgical exploration and histologic assessment. Spine (Phila Pa 1976) 31: 1067-1074.

Kasper G, Dankert N, Tuischer J, Hoeft M, Gaber T, Glaeser JD, Zander D, Tschirschmann M, Thompson M, Matziolis G, Duda GN (2007) Mesenchymal stem cells regulate angiogenesis according to their mechanical environment. Stem Cells 25: 903-910.

Kim HK, Shim WS, Kim SE, Lee KH, Kang E, Kim JH, Kim K, Kwon IC, Lee DS (2009) Injectable in situ-forming $\mathrm{pH} /$ thermo-sensitive hydrogel for bone tissue engineering. Tissue Eng Part A 15: 923-933.

Kim J, Magno MH, Waters H, Doll BA, McBride S, Alvarez P, Darr A, Vasanji A, Kohn J, Hollinger JO (2012) Bone regeneration in a rabbit critical-sized calvarial model using tyrosine-derived polycarbonate scaffolds. Tissue Eng Part A 18: 1132-1139.

Kim KS, Lee JY, Kang YM, Kim ES, Kim GH, Rhee SD, Cheon HG, Kim JH, Min BH, Lee HB, Kim MS (2010) Small intestine submucosa sponge for in vivo support of tissue-engineered bone formation in the presence of rat bone marrow stem cells. Biomaterials 31: 1104-1113.

Kimelman-Bleich N, Pelled G, Zilberman Y, Kallai I, Mizrahi O, Tawackoli W, Gazit Z, Gazit D (2011) Targeted gene-and-host progenitor cell therapy for nonunion bone fracture repair. Mol Ther 19: 53-59.

King WJ, Krebsbach PH (2012) Growth factor delivery: how surface interactions modulate release in vitro and in vivo. Adv Drug Deliv Rev 64: 1239-1256.

Klein P, Schell H, Streitparth F, Heller M, Kassi JP, Kandziora F, Bragulla H, Haas NP, Duda GN (2003) The initial phase of fracture healing is specifically sensitive to mechanical conditions. J Orthop Res 21: 662-669.

Ko JY, Im GI (2014) Chondrogenic and osteogenic induction from iPS cells. Methods Mol Biol 1357: 441-450.

Koike N, Fukumura D, Gralla O, Au P, Schechner JS, Jain RK (2004) Tissue engineering: creation of long-lasting blood vessels. Nature 428: 138-139.

Kolambkar YM, Boerckel JD, Dupont KM, Bajin M, Huebsch N, Mooney DJ, Hutmacher DW, Guldberg RE (2011) Spatiotemporal delivery of bone morphogenetic protein enhances functional repair of segmental bone defects. Bone 49: 485-492.

Krebs MD, Salter E, Chen E, Sutter KA, Alsberg E (2010) Calcium phosphate-DNA nanoparticle gene 
delivery from alginate hydrogels induces in vivo osteogenesis. J Biomed Mater Res A 92: 1131-1138.

Kuhn LT, Liu Y, Boyd NL, Dennis JE, Jiang X, Xin X, Charles LF, Wang L, Aguila HL, Rowe DW, Lichtler AC, Goldberg AJ (2014) Developmental-like bone regeneration by human embryonic stem cell-derived mesenchymal cells. Tissue Eng Part A 20: 365-377.

Kuroda R, Matsumoto T, Niikura T, Kawakami Y, Fukui T, Lee SY, Mifune Y, Kawamata S, Fukushima M, Asahara T, Kawamoto A, Kurosaka M (2014) Local transplantation of granulocyte colony stimulating factor-mobilized CD34+ cells for patients with femoral and tibial nonunion: pilot clinical trial. Stem Cells Transl Med 3: 128-134.

Laschke MW, Menger MD (2012) Vascularization in tissue engineering: angiogenesis versus inosculation. Eur Surg Res 48: 85-92.

Laschke MW, Menger MD (2015) Adipose tissuederived microvascular fragments: natural vascularization units for regenerative medicine. Trends Biotechnol 33: 442-448.

Laschke MW, Menger MD (2016) Prevascularization in tissue engineering: Current concepts and future directions. Biotechnol Adv 34: 112-121.

Laschke MW, Mussawy H, Schuler S, Kazakov A, Rücker M, Eglin D, Alini M, Menger MD (2011) Shortterm cultivation of in situ prevascularized tissue constructs accelerates inosculation of their preformed microvascular networks after implantation into the host tissue. Tissue Eng Part A 17: 841-853.

Laschke MW, Schank TE, Scheuer C, Kleer S, Schuler S, Metzger W, Eglin D, Alini M, Menger MD (2013) Threedimensional spheroids of adipose-derived mesenchymal stem cells are potent initiators of blood vessel formation in porous polyurethane scaffolds. Acta Biomater 9: 68766884.

Lattanzi W, Parrilla C, Fetoni A, Logroscino G, Straface G, Pecorini G, Stigliano E, Tampieri A, Bedini R, Pecci R, Michetti F, Gambotto A, Robbins PD, Pola E (2008) Ex vivo-transduced autologous skin fibroblasts expressing human Lim mineralization protein-3 efficiently form new bone in animal models. Gene Ther 15: 1330-1343.

Le AX, Miclau T, Hu D, Helms JA (2001) Molecular aspects of healing in stabilized and non-stabilized fractures. J Orthop Res 19: 78-84.

Lee JS, Lee JS, Murphy WL (2010a) Modular peptides promote human mesenchymal stem cell differentiation on biomaterial surfaces. Acta Biomater 6: 21-28.

Lee JS, Wagoner Johnson AJ, Murphy WL (2010b) A modular, hydroxyapatite-binding version of vascular endothelial growth factor. Adv Mater 22: 5494-5498.

Lee K, Chan CK, Patil N, Goodman SB (2009) Cell therapy for bone regeneration - bench to bedside. J Biomed Mater Res B Appl Biomater 89: 252-263.

Lee KY, Mooney DJ (2012) Alginate: properties and biomedical applications. Prog Polym Sci 37: 106-126.

Lee RJ, Springer ML, Blanco-Bose WE, Shaw R, Ursell PC, Blau HM (2000) VEGF gene delivery to myocardium: deleterious effects of unregulated expression. Circulation 102: 898-901.

Levi B, Nelson ER, Hyun JS, Glotzbach JP, Li S, Nauta A, Montoro DT, Lee M, Commons GC, Hu S, Wu
JC, Gurtner GC, Longaker MT (2012) Enhancement of human adipose-derived stromal cell angiogenesis through knockdown of a BMP-2 inhibitor. Plast Reconstr Surg 129: 53-66.

Li BC, Zhang JJ, Xu C, Zhang LC, Kang JY, Zhao H (2009a) Treatment of rabbit femoral defect by firearm with BMP-4 gene combined with TGF-beta1. J Trauma 66: 450-456.

Li H, Dai K, Tang T, Zhang X, Yan M, Lou J (2007) Bone regeneration by implantation of adipose-derived stromal cells expressing BMP-2. Biochem Biophys Res Commun 356: 836-842.

Li R, Stewart DJ, von Schroeder HP, Mackinnon ES, Schemitsch EH (2009b) Effect of cell-based VEGF gene therapy on healing of a segmental bone defect. J Orthop Res 27: 8-14.

Li Y, Fan L, Liu S, Liu W, Zhang H, Zhou T, Wu D, Yang P, Shen L, Chen J, Jin Y (2013) The promotion of bone regeneration through positive regulation of angiogenic-osteogenic coupling using microRNA-26a. Biomaterials 34: 5048-5058.

Lieberman JR, Daluiski A, Stevenson S, Wu L, McAllister P, Lee YP, Kabo JM, Finerman GA, Berk AJ, Witte ON (1999) The effect of regional gene therapy with bone morphogenetic protein-2-producing bone-marrow cells on the repair of segmental femoral defects in rats. $\mathrm{J}$ Bone Joint Surg Am 81: 905-917.

Lin CY, Chang YH, Kao CY, Lu CH, Sung LY, Yen TC, Lin KJ, Hu YC (2012) Augmented healing of criticalsize calvarial defects by baculovirus-engineered MSCs that persistently express growth factors. Biomaterials 33: 3682-3692.

Lin Y, Weisdorf DJ, Solovey A, Hebbel RP (2000) Origins of circulating endothelial cells and endothelial outgrowth from blood. J Clin Invest 105: 71-77.

Lippross S, Loibl M, Hoppe S, Meury T, Benneker L, Alini M, Verrier S (2011) Platelet released growth factors boost expansion of bone marrow derived CD34(+) and CD133(+) endothelial progenitor cells for autologous grafting. Platelets 22: 422-432.

Liu J, Chen W, Zhao Z, Xu HH (2013) Reprogramming of mesenchymal stem cells derived from iPSCs seeded on biofunctionalized calcium phosphate scaffold for bone engineering. Biomaterials 34: 7862-7872.

Loi F, Cordova LA, Zhang R, Pajarinen J, Lin TH, Goodman SB, Yao Z (2016) The effects of immunomodulation by macrophage subsets on osteogenesis in vitro. Stem Cell Res Ther 7: 15.

Lu Y, Markel MD, Nemke B, Lee JS, Graf BK, Murphy WL (2009) Influence of hydroxyapatite-coated and growth factor-releasing interference screws on tendon-bone healing in an ovine model. Arthroscopy 25: 1427-1434.

Luangphakdy V, Walker E, Shinohara K, Pan H, Hefferan T, Bauer TW, Stockdale L, Saini S, Dadsetan M, Runge MB, Vasanji A, Griffith L, Yaszemski M, Muschler GF (2013) Evaluation of osteoconductive scaffolds in the canine femoral multi-defect model. Tissue Eng Part A 19: 634-648.

Lucarelli E, Fini M, Beccheroni A, Giavaresi G, Di Bella C, Aldini NN, Guzzardella G, Martini L, Cenacchi A, Di Maggio N, Sangiorgi L, Fornasari PM, Mercuri 
M, Giardino R, Donati D (2005) Stromal stem cells and platelet-rich plasma improve bone allograft integration. Clin Orthop Relat Res 62-68.

Lyons FG, Al-Munajjed AA, Kieran SM, Toner ME, Murphy CM, Duffy GP, O’Brien FJ (2010) The healing of bony defects by cell-free collagen-based scaffolds compared to stem cell-seeded tissue engineered constructs. Biomaterials 31: 9232-9243.

Madry H, Alini M, Stoddart MJ, Evans C, Miclau T, Steiner S (2014) Barriers and strategies for the clinical translation of advanced orthopaedic tissue engineering protocols. Eur Cell Mater 27: 17-21.

Maraldi T, Riccio M, Pisciotta A, Zavatti M, Carnevale G, Beretti F, La Sala GB, Motta A, De PA (2013) Human amniotic fluid-derived and dental pulp-derived stem cells seeded into collagen scaffold repair critical-size bone defects promoting vascularization. Stem Cell Res Ther 4: 53.

Masuda H, Asahara T (2003) Post-natal endothelial progenitor cells for neovascularization in tissue regeneration. Cardiovasc Res 58: 390-398.

Matthews JA, Wnek GE, Simpson DG, Bowlin GL (2002) Electrospinning of collagen nanofibers. Biomacromolecules 3: 232-238.

Mifune Y, Matsumoto T, Kawamoto A, Kuroda R, Shoji T, Iwasaki H, Kwon SM, Miwa M, Kurosaka M, Asahara $\mathrm{T}$ (2008) Local delivery of granulocyte colony stimulating factor-mobilized CD34-positive progenitor cells using bioscaffold for modality of unhealing bone fracture. Stem Cells 26: 1395-1405.

Moore DC, Pedrozo HA, Crisco JJ III, Ehrlich MG (2004) Preformed grafts of porcine small intestine submucosa (SIS) for bridging segmental bone defects. J Biomed Mater Res A 69: 259-266.

Murphy WL, Hsiong S, Richardson TP, Simmons CA, Mooney DJ (2005) Effects of a bone-like mineral film on phenotype of adult human mesenchymal stem cells in vitro. Biomaterials 26: 303-310.

Musgrave DS, Bosch P, Ghivizzani S, Robbins PD, Evans CH, Huard J (1999) Adenovirus-mediated direct gene therapy with bone morphogenetic protein-2 produces bone. Bone 24: 541-547.

Nguyen TH, Kim SH, Decker CG, Wong DY, Loo JA, Maynard HD (2013) A heparin-mimicking polymer conjugate stabilizes basic fibroblast growth factor. Nat Chem 5: 221-227.

Niemeyer P, Fechner K, Milz S, Richter W, Suedkamp NP, Mehlhorn AT, Pearce S, Kasten P (2010) Comparison of mesenchymal stem cells from bone marrow and adipose tissue for bone regeneration in a critical size defect of the sheep tibia and the influence of platelet-rich plasma. Biomaterials 31: 3572-3579.

O'Brien FJ (2011) Biomaterials \& scaffolds for tissue engineering. Materials today 14: 88-95.

Pachon-Pena G, Yu G, Tucker A, Wu X, Vendrell J, Bunnell BA, Gimble JM (2011) Stromal stem cells from adipose tissue and bone marrow of age-matched female donors display distinct immunophenotypic profiles. J Cell Physiol 226: 843-851.

Palmer GD, Steinert A, Pascher A, Gouze E, Gouze JN, Betz O, Johnstone B, Evans CH, Ghivizzani SC (2005)
Gene-induced chondrogenesis of primary mesenchymal stem cells in vitro. Mol Ther 12: 219-228.

Parekkadan B, Milwid JM (2010) Mesenchymal stem cells as therapeutics. Annu Rev Biomed Eng 12: 87-117.

Park BH, Zhou L, Jang KY, Park HS, Lim JM, Yoon SJ, Lee SY, Kim JR (2012) Enhancement of tibial regeneration in a rat model by adipose-derived stromal cells in a PLGA scaffold. Bone 51: 313-323.

Park H, Choi B, Nguyen J, Fan J, Shafi S, Klokkevold P, Lee M (2013) Anionic carbohydrate-containing chitosan scaffolds for bone regeneration. Carbohydr Polym 97: 587596.

Peichev M, Naiyer AJ, Pereira D, Zhu Z, Lane WJ, Williams M, Oz MC, Hicklin DJ, Witte L, Moore MA, Rafii S (2000) Expression of VEGFR-2 and AC133 by circulating human $\mathrm{CD} 34(+)$ cells identifies a population of functional endothelial precursors. Blood 95: 952-958.

Pelttari K, Winter A, Steck E, Goetzke K, Hennig T, Ochs BG, Aigner T, Richter W (2006) Premature induction of hypertrophy during in vitro chondrogenesis of human mesenchymal stem cells correlates with calcification and vascular invasion after ectopic transplantation in SCID mice. Arthritis Rheum 54: 3254-3266.

Pensak MJ, Lieberman JR (2013) Gene therapy for bone regeneration. Curr Pharm Des 19: 3466-3473.

Peterson B, Whang PG, Iglesias R, Wang JC, Lieberman JR (2004) Osteoinductivity of commercially available demineralized bone matrix. Preparations in a spine fusion model. J Bone Joint Surg Am 86-A: 22432250.

Peterson B, Zhang J, Iglesias R, Kabo M, Hedrick M, Benhaim P, Lieberman JR (2005) Healing of critically sized femoral defects, using genetically modified mesenchymal stem cells from human adipose tissue. Tissue Eng 11: 120129.

Pighinelli L, Kucharska M (2013) Chitosanhydroxyapatite composites. Carbohydr Polym 93: 256-262.

Qu D, Li J, Li Y, Gao Y, Zuo Y, Hsu Y, Hu J (2011) Angiogenesis and osteogenesis enhanced by bFGF ex vivo gene therapy for bone tissue engineering in reconstruction of calvarial defects. J Biomed Mater Res A 96: 543-551.

Quarto R, Mastrogiacomo M, Cancedda R, Kutepov SM, Mukhachev V, Lavroukov A, Kon E, Marcacci M (2001) Repair of large bone defects with the use of autologous bone marrow stromal cells. N Engl J Med 344: 385-386.

Rao RR, Peterson AW, Stegemann JP (2013) Winner for outstanding research in the Ph.D. category for the 2013 Society for Biomaterials meeting and exposition, April 10-13, 2013, Boston, Massachusetts: Osteogenic differentiation of adipose-derived and marrow-derived mesenchymal stem cells in modular protein/ceramic microbeads. J Biomed Mater Res A 101: 1531-1538.

Rao RR, Vigen ML, Peterson AW, Caldwell DJ, Putnam AJ, Stegemann JP (2015) Dual-phase osteogenic and vasculogenic engineered tissue for bone formation. Tissue Eng Part A 21: 530-540.

Raper SE, Chirmule N, Lee FS, Wivel NA, Bagg A, Gao GP, Wilson JM, Batshaw ML (2003) Fatal systemic inflammatory response syndrome in a ornithine 
transcarbamylase deficient patient following adenoviral gene transfer. Mol Genet Metab 80: 148-158.

Ratanavaraporn J, Furuya H, Kohara H, Tabata Y (2011) Synergistic effects of the dual release of stromal cell-derived factor- 1 and bone morphogenetic protein-2 from hydrogels on bone regeneration. Biomaterials 32: 2797-2811.

Reves BT, Bumgardner JD, Haggard WO (2013) Fabrication of crosslinked carboxymethylchitosan microspheres and their incorporation into composite scaffolds for enhanced bone regeneration. J Biomed Mater Res B Appl Biomater 101: 630-639.

Rizzi SC, Ehrbar M, Halstenberg S, Raeber GP, Schmoekel HG, Hagenmuller H, Muller R, Weber FE, Hubbell JA (2006) Recombinant protein-co-PEG networks as cell-adhesive and proteolytically degradable hydrogel matrixes. Part II: biofunctional characteristics. Biomacromolecules 7: 3019-3029.

Rosenbaum AJ, Grande DA, Dines JS (2008) The use of mesenchymal stem cells in tissue engineering: A global assessment. Organogenesis 4: 23-27.

Rundle CH, Strong DD, Chen ST, Linkhart TA, Sheng MH, Wergedal JE, Lau KH, Baylink DJ (2008) Retroviralbased gene therapy with cyclooxygenase- 2 promotes the union of bony callus tissues and accelerates fracture healing in the rat. J Gene Med 10: 229-241.

Rundle CH, Wang H, Yu H, Chadwick RB, Davis EI, Wergedal JE, Lau KH, Mohan S, Ryaby JT, Baylink DJ (2006) Microarray analysis of gene expression during the inflammation and endochondral bone formation stages of rat femur fracture repair. Bone 38: 521-529.

Salinas CN, Anseth KS (2009) Mesenchymal stem cells for craniofacial tissue regeneration: designing hydrogel delivery vehicles. J Dent Res 88: 681-692.

Sandor GK, Tuovinen VJ, Wolff J, Patrikoski M, Jokinen J, Nieminen E, Mannerstrom B, Lappalainen OP, Seppanen R, Miettinen S (2013) Adipose stem cell tissueengineered construct used to treat large anterior mandibular defect: a case report and review of the clinical application of good manufacturing practice-level adipose stem cells for bone regeneration. J Oral Maxillofac Surg 71: 938-950.

Sawkins MJ, Bowen W, Dhadda P, Markides H, Sidney LE, Taylor AJ, Rose FR, Badylak SF, Shakesheff KM, White LJ (2013) Hydrogels derived from demineralized and decellularized bone extracellular matrix. Acta Biomater 9: 7865-7873.

Schantz JT, Chim H, Whiteman M (2007) Cell guidance in tissue engineering: SDF-1 mediates site-directed homing of mesenchymal stem cells within three-dimensional polycaprolactone scaffolds. Tissue Eng 13: 2615-2624.

Schmoekel HG, Weber FE, Schense JC, Gratz KW, Schawalder P, Hubbell JA (2005) Bone repair with a form of BMP-2 engineered for incorporation into fibrin cell ingrowth matrices. Biotechnol Bioeng 89: 253-262.

Schumann P, Tavassol F, Lindhorst D, Stuehmer C, Bormann KH, Kampmann A, Mulhaupt R, Laschke MW, Menger MD, Gellrich NC, Rucker M (2009) Consequences of seeded cell type on vascularization of tissue engineering constructs in vivo. Microvasc Res 78: 180-190.
Schwartz R, Reddi AH (1979) Influence of magnesium depletion on matrix-induced endochondral bone formation. Calcif Tissue Int 29: 15-20.

Scotti C, Piccinini E, Takizawa H, Todorov A, Bourgine P, Papadimitropoulos A, Barbero A, Manz MG, Martin I (2013) Engineering of a functional bone organ through endochondral ossification. Proc Natl Acad Sci U S A 110: 3997-4002.

Scotti C, Tonnarelli B, Papadimitropoulos A, Scherberich A, Schaeren S, Schauerte A, Lopez-Rios J, Zeller R, Barbero A, Martin I (2010) Recapitulation of endochondral bone formation using human adult mesenchymal stem cells as a paradigm for developmental engineering. Proc Natl Acad Sci U S A 107: 7251-7256.

Seebach C, Henrich D, Kahling C, Wilhelm K, Tami AE, Alini M, Marzi I (2010) Endothelial progenitor cells and mesenchymal stem cells seeded onto beta-TCP granules enhance early vascularization and bone healing in a critical-sized bone defect in rats. Tissue Eng Part A 16: 1961-1970.

Seeherman H, Wozney JM (2005) Delivery of bone morphogenetic proteins for orthopedic tissue regeneration. Cytokine Growth Factor Rev 16: 329-345.

Shah RN, Shah NA, Del Rosario Lim MM, Hsieh C, Nuber G, Stupp SI (2010) Supramolecular design of selfassembling nanofibers for cartilage regeneration. Proc Natl Acad Sci U S A 107: 3293-3298.

Sheehy EJ, Vinardell T, Buckley CT, Kelly DJ (2013) Engineering osteochondral constructs through spatial regulation of endochondral ossification. Acta Biomater 9: 5484-5492.

Shekaran A, Garcia AJ (2011) Extracellular matrixmimetic adhesive biomaterials for bone repair. J Biomed Mater Res A 96: 261-272.

Shih YR, Hwang Y, Phadke A, Kang H, Hwang NS, Caro EJ, Nguyen S, Siu M, Theodorakis EA, Gianneschi NC, Vecchio KS, Chien S, Lee OK, Varghese S (2014) Calcium phosphate-bearing matrices induce osteogenic differentiation of stem cells through adenosine signaling. Proc Natl Acad Sci U S A 111: 990-995.

Siebers MC, ter Brugge PJ, Walboomers XF, Jansen JA (2005) Integrins as linker proteins between osteoblasts and bone replacing materials. A critical review. Biomaterials 26: 137-146.

Solorio LD, Dhami CD, Dang PN, Vieregge EL, Alsberg E (2012) Spatiotemporal regulation of chondrogenic differentiation with controlled delivery of transforming growth factor-beta1 from gelatin microspheres in mesenchymal stem cell aggregates. Stem Cells Transl Med 1: 632-639.

Solorio LD, Phillips LM, McMillan A, Cheng CW, Dang PN, Samorezov JE, Yu X, Murphy WL, Alsberg E (2015) Spatially organized differentiation of mesenchymal stem cells within biphasic microparticle-incorporated high cell density osteochondral tissues. Adv Healthc Mater 4: 2306-2313.

Steinert AF, Proffen B, Kunz M, Hendrich C, Ghivizzani SC, Noth U, Rethwilm A, Eulert J, Evans $\mathrm{CH}$ (2009) Hypertrophy is induced during the in vitro 
chondrogenic differentiation of human mesenchymal stem cells by bone morphogenetic protein-2 and bone morphogenetic protein-4 gene transfer. Arthritis Res Ther 11: R148.

Strioga M, Viswanathan S, Darinskas A, Slaby O, Michalek J (2012) Same or not the same? Comparison of adipose tissue-derived versus bone marrow-derived mesenchymal stem and stromal cells. Stem Cells Dev 21: 2724-2752.

Su J, Xu H, Sun J, Gong X, Zhao H (2013) Dual delivery of BMP-2 and bFGF from a New nano-composite scaffold, loaded with vascular stents for large-size mandibular defect regeneration. Int J Mol Sci 14: 12714-12728.

Suarez-Gonzalez D, Barnhart K, Migneco F, Flanagan C, Hollister SJ, Murphy WL (2012) Controllable mineral coatings on PCL scaffolds as carriers for growth factor release. Biomaterials 33: 713-721.

Sun XJ, Peng W, Yang ZL, Ren ML, Zhang SC, Zhang WG, Zhang LY, Xiao K, Wang ZG, Zhang B, Wang J (2011) Heparin-chitosan-coated acellular bone matrix enhances perfusion of blood and vascularization in bone tissue engineering scaffolds. Tissue Eng Part A 17: 2369-2378.

Tavassol F, Schumann P, Lindhorst D, Sinikovic B, Voss A, von See C, Kampmann A, Bormann KH, Carvalho C, Mulhaupt R, Harder Y, Laschke MW, Menger MD, Gellrich NC, Rücker M (2010) Accelerated angiogenic host tissue response to poly(L-lactide-co-glycolide) scaffolds by vitalization with osteoblast-like cells. Tissue Eng Part A 16: 2265-2279.

Thompson AD, Betz MW, Yoon DM, Fisher JP (2009) Osteogenic differentiation of bone marrow stromal cells induced by coculture with chondrocytes encapsulated in three-dimensional matrices. Tissue Eng Part A 15: 11811190 .

Thompson EM, Matsiko A, Farrell E, Kelly DJ, O’Brien FJ (2014) Recapitulating endochondral ossification: a promising route to in vivo bone regeneration. J Tissue Eng Regen Med 9: 889-902.

Thompson EM, Matsiko A, Kelly DJ, Gleeson J, O'Brien FJ (2016) An endochondral ossification-based approach to bone repair: Chondrogenically-primed MSCladen scaffolds support greater repair of critical-sized cranial defects than osteogenically stimulated constructs in vivo. Tissue Eng Part A 22: 556-567.

Thompson Z, Miclau T, Hu D, Helms JA (2002) A model for intramembranous ossification during fracture healing. J Orthop Res 20: 1091-1098.

Thornton AJ, Alsberg E, Albertelli M, Mooney DJ (2004) Shape-defining scaffolds for minimally invasive tissue engineering. Transplantation 77: 1798-1803.

Thorpe SD, Nagel T, Carroll SF, Kelly DJ (2013) Modulating gradients in regulatory signals within mesenchymal stem cell seeded hydrogels: a novel strategy to engineer zonal articular cartilage. PLoS One 8: e60764.

Tierney EG, Duffy GP, Cryan SA, Curtin CM, O’Brien FJ (2013) Non-viral gene-activated matrices: next generation constructs for bone repair. Organogenesis 9: 22-28.

Tierney EG, Duffy GP, Hibbitts AJ, Cryan SA, O’Brien FJ (2012) The development of non-viral gene-activated matrices for bone regeneration using polyethyleneimine
(PEI) and collagen-based scaffolds. J Control Release 158: 304-311.

Tortelli F, Tasso R, Loiacono F, Cancedda R (2010) The development of tissue-engineered bone of different origin through endochondral and intramembranous ossification following the implantation of mesenchymal stem cells and osteoblasts in a murine model. Biomaterials 31: 242-249.

Tu Q, Valverde P, Li S, Zhang J, Yang P, Chen J (2007) Osterix overexpression in mesenchymal stem cells stimulates healing of critical-sized defects in murine calvarial bone. Tissue Eng 13: 2431-2440.

Urist MR (1965) Bone: formation by autoinduction. Science 150: 893-899.

Utzinger U, Baggett B, Weiss JA, Hoying JB, Edgar LT (2015) Large-scale time series microscopy of neovessel growth during angiogenesis. Angiogenesis 18: 219-232.

Vacanti CA, Bonassar LJ, Vacanti MP, Shufflebarger J (2001) Replacement of an avulsed phalanx with tissueengineered bone. N Engl J Med 344: 1511-1514.

Venkatesan J, Pallela R, Bhatnagar I, Kim SK (2012) Chitosan-amylopectin/hydroxyapatite and chitosanchondroitin sulphate/hydroxyapatite composite scaffolds for bone tissue engineering. Int J Biol Macromol 51: 1033 1042.

Vinardell T, Rolfe RA, Buckley CT, Meyer EG, Ahearne M, Murphy P, Kelly DJ (2012a) Hydrostatic pressure acts to stabilise a chondrogenic phenotype in porcine joint tissue derived stem cells. Eur Cell Mater 23: 121-132.

Vinardell T, Sheehy EJ, Buckley CT, Kelly DJ (2012b) A comparison of the functionality and in vivo phenotypic stability of cartilaginous tissues engineered from different stem cell sources. Tissue Eng Part A 18: 1161-1170.

Virk MS, Sugiyama O, Park SH, Gambhir SS, Adams DJ, Drissi H, Lieberman JR (2011) "Same day" ex-vivo regional gene therapy: a novel strategy to enhance bone repair. Mol Ther 19: 960-968.

Wahl DA, Czernuszka JT (2006) Collagenhydroxyapatite composites for hard tissue repair. Eur Cell Mater 11: 43-56.

Wallace AL, Draper ER, Strachan RK, McCarthy ID, Hughes SP (1994) The vascular response to fracture micromovement. Clin Orthop Relat Res 281-290.

Wang L, Rao RR, Stegemann JP (2013) Delivery of mesenchymal stem cells in chitosan/collagen microbeads for orthopedic tissue repair. Cells Tissues Organs 197: 333-343.

Wang L, Stegemann JP (2010) Thermogelling chitosan and collagen composite hydrogels initiated with betaglycerophosphate for bone tissue engineering. Biomaterials 31: 3976-3985.

Wang L, Stegemann JP (2011) Glyoxal crosslinking of cell-seeded chitosan/collagen hydrogels for bone regeneration. Acta Biomater 7: 2410-2417.

Wang S, Lu L, Yaszemski MJ (2006) Bone-tissueengineering material poly(propylene fumarate): correlation between molecular weight, chain dimensions, and physical properties. Biomacromolecules 7: 1976-1982.

Wang ZZ, Au P, Chen T, Shao Y, Daheron LM, Bai H, Arzigian M, Fukumura D, Jain RK, Scadden DT (2007) Endothelial cells derived from human embryonic stem 
cells form durable blood vessels in vivo. Nat Biotechnol 25: $317-318$.

Warnke PH, Springer IN, Wiltfang J, Acil Y, Eufinger H, Wehmoller M, Russo PA, Bolte H, Sherry E, Behrens E, Terheyden H (2004) Growth and transplantation of a custom vascularised bone graft in a man. Lancet 364: 766-770.

Weaver AS, Su YP, Begun DL, Miller JD, Alford AI, Goldstein SA (2010) The effects of axial displacement on fracture callus morphology and MSC homing depend on the timing of application. Bone 47: 41-48.

Webber MJ, Tongers J, Renault MA, Roncalli JG, Losordo DW, Stupp SI (2010) Development of bioactive peptide amphiphiles for therapeutic cell delivery. Acta Biomater 6: 3-11.

Wei S, Cai X, Huang J, Xu F, Liu X, Wang Q (2012) Recombinant human BMP-2 for the treatment of open tibial fractures. Orthopedics 35: e847-e854.

Whitney MJ, Lee A, Ylostalo J, Zeitouni S, Tucker A, Gregory CA (2009) Leukemia inhibitory factor secretion is a predictor and indicator of early progenitor status in adult bone marrow stromal cells. Tissue Eng Part A 15: 33-44.

Wise JK, Alford AI, Goldstein SA, Stegemann JP (2015) Synergistic enhancement of ectopic bone formation by supplementation of freshly isolated marrow cells with purified MSC in collagen-chitosan hydrogel microbeads. Connect Tissue Res 4: 1-9.

Wolf S, Janousek A, Pfeil J, Veith W, Haas F, Duda G, Claes L (1998) The effects of external mechanical stimulation on the healing of diaphyseal osteotomies fixed by flexible external fixation. Clin Biomech (Bristol, Avon) 13: $359-364$.

Woodruff MA, Rath SN, Susanto E, Haupt LM, Hutmacher DW, Nurcombe V, Cool SM (2007) Sustained release and osteogenic potential of heparan sulfate-doped fibrin glue scaffolds within a rat cranial model. J Mol Histol 38: $425-433$.

Wu X, Wang Q, Kang N, Wu J, Gu C, Bi J, Lv T, Xie F, Hu J, Liu X, Cao Y, Xiao R (2015) The effects of different vascular carrier patterns on the angiogenesis and osteogenesis of BMSC-TCP-based tissue-engineered bone in beagle dogs. J Tissue Eng Regen Med doi: 10.1002/ term.2076.

Yamaji T, Ando K, Wolf S, Augat P, Claes L (2001) The effect of micromovement on callus formation. J Orthop Sci 6: 571-575.

Yamamoto M, Takahashi Y, Tabata Y (2003) Controlled release by biodegradable hydrogels enhances the ectopic bone formation of bone morphogenetic protein. Biomaterials 24: 4375-4383.

Yamamoto M, Takahashi Y, Tabata Y (2006) Enhanced bone regeneration at a segmental bone defect by controlled release of bone morphogenetic protein-2 from a biodegradable hydrogel. Tissue Eng 12: 1305-1311.

Yang F, Yang D, Tu J, Zheng Q, Cai L, Wang L (2011) Strontium enhances osteogenic differentiation of mesenchymal stem cells and in vivo bone formation by activating Wnt/catenin signaling. Stem Cells 29: 981-991.

Yang H, Yang S, Chi X, Evans JR (2006) Fine ceramic lattices prepared by extrusion freeforming. J Biomed Mater Res B Appl Biomater 79: 116-121.
Yang W, Both SK, van Osch GJ, Wang Y, Jansen JA, Yang F (2015) Effects of in vitro chondrogenic priming time of bone-marrow-derived mesenchymal stromal cells on in vivo endochondral bone formation. Acta Biomater 13: 254-265.

Yang W, Yang F, Wang Y, Both SK, Jansen JA (2013) In vivo bone generation via the endochondral pathway on three-dimensional electrospun fibers. Acta Biomater 9: 4505-4512.

Yi T, Song SU (2012) Immunomodulatory properties of mesenchymal stem cells and their therapeutic applications. Arch Pharm Res 35: 213-221.

Yong MR, Saifzadeh S, Askin GN, Labrom RD, Hutmacher DW, Adam CJ (2014) Biological performance of a polycaprolactone-based scaffold plus recombinant human morphogenetic protein-2 (rhBMP-2) in an ovine thoracic interbody fusion model. Eur Spine J 23: 650-657.

Yousefi AM, James PF, Akbarzadeh R, Subramanian A, Flavin C, Oudadesse H (2016) Prospect of stem cells in bone tissue engineering: a review. Stem Cells Int 2016: 6180487.

Yu NY, Schindeler A, Little DG, Ruys AJ (2010) Biodegradable poly(alpha-hydroxy acid) polymer scaffolds for bone tissue engineering. J Biomed Mater Res B Appl Biomater 93: 285-295.

Zeitouni S, Krause U, Clough BH, Halderman H, Falster A, Blalock DT, Chaput CD, Sampson HW, Gregory CA (2012) Human mesenchymal stem cell-derived matrices for enhanced osteoregeneration. Sci Transl Med 4: 132ra55.

Zhang H, Migneco F, Lin CY, Hollister SJ (2010a) Chemically-conjugated bone morphogenetic protein-2 on three-dimensional polycaprolactone scaffolds stimulates osteogenic activity in bone marrow stromal cells. Tissue Eng Part A 16: 3441-3448.

Zhang Y, Venugopal JR, El-Turki A, Ramakrishna S, Su B, Lim CT (2008) Electrospun biomimetic nanocomposite nanofibers of hydroxyapatite/chitosan for bone tissue engineering. Biomaterials 29: 4314-4322.

Zhang ZY, Teoh SH, Chong MS, Lee ES, Tan LG, Mattar CN, Fisk NM, Choolani M, Chan J (2010b) Neovascularization and bone formation mediated by fetal mesenchymal stem cell tissue-engineered bone grafts in critical-size femoral defects. Biomaterials 31: 608-620.

Zheng H, Bai Y, Shih MS, Hoffmann C, Peters F, Waldner C, Hubner WD (2014) Effect of a beta-TCP collagen composite bone substitute on healing of drilled bone voids in the distal femoral condyle of rabbits. J Biomed Mater Res B Appl Biomater 102: 376-383.

Zhu G, Mallery SR, Schwendeman SP (2000) Stabilization of proteins encapsulated in injectable poly (lactide- co-glycolide). Nat Biotechnol 18: 52-57.

Zou D, Zhang Z, He J, Zhang K, Ye D, Han W, Zhou J, Wang Y, Li Q, Liu X, Zhang X, Wang S, Hu J, Zhu C, Zhang W, zhou Y, Fu H, Huang Y, Jiang X (2012) Blood vessel formation in the tissue-engineered bone with the constitutively active form of HIF-1alpha mediated BMSCs. Biomaterials 33: 2097-2108. 


\section{Discussion with Reviewers}

P. Habibovic: In the Conclusion section, the authors state: "At a minimum, the regeneration of bone requires the balanced contributions of scaffolds, cells, morphogenetic signals, vascularisation and mechanics". I would like to challenge this statement by stating that a therapy encompassing all these component will never reach the clinic, because of the high cost and complex regulations. Could the authors respond to this statement?

Authors: The reviewer identifies an important issue that is touched upon in the paper, but not explored in detail: how to make TERM (Tissue Engineering and Regenerative Medicine) affordable. This will probably require expedited approaches that do not use expanded, autologous cells but harness intrinsic, biological processes. Greater investigation of simple rehabilitation techniques could also pay dividends. Investigators need to bear in mind cost, as well as science, when developing technologies.

I. Martin: In the conclusions, it is mentioned that "perhaps, we need to go back to the beginning and discover why large segmental defects in otherwise healthy individuals do not heal". Could you further elaborate your recommendation on the approaches to be followed or nature of the parameters to be investigated to bring forward our fundamental knowledge of the biological processes which need to be better controlled?

Authors: The early biological responses to an osseous injury seem important determinants of whether and, if so, how, a defect will heal (Glatt et al., eCM 2012; Kolar al, Tissue Engineering Part B. 2010). This suggests that study of the early biology of a segmental defect would be profitable. Useful comparisons could be made between a critical sized defect in the presence or absence of an osteogenic growth factor, or between a large osseous in a bone that does not heal (e.g. femur) and one where a similar sized defect spontaneously heals (e.g. rib). Preparadigmatic observations in such systems promise to generate experimentally testable hypotheses.

Editor's note: The Scientific Editor responsible for this paper was Joost de Bruijn. 